\title{
Expectations and industrial output in Uruguay: Sectoral interdependence and common trends
}

\author{
Bibiana Lanzilotta
}

ABSTRACT

KEYWORDS

JEL CLASSIFICATION

AUTHOR
This paper examines the interdependence between expectations and growth by analysing Uruguayan manufacturing industry, divided for the purpose into four industry groupings differentiated by trade participation and production specialization. The study shows that there is a long-run relationship between industrialists' expectations and output growth in each grouping. In the most trade-oriented groupings the relationship is one of predetermination, showing how useful expectations are as a guide to sectoral growth. Expectations in the four industrial groupings are shown to follow a common long-run trend, identified with the one guiding the export grouping. Impulse-response simulations derived from a multisectoral vector autoregression (VAR) model confirm the important role of the industries most exposed to international competition in spreading shorter-term shocks. 


\section{I}

\section{Introduction}

Both economic theory and applied research have demonstrated the importance of studying expectations as they relate to economic fundamentals and cyclical fluctuations. Empirical studies conducted in the past few years have stressed the influence of expectations in inducing and amplifying recent international fluctuations (Karnizova, 2010; Leduc and Sill, 2010; Patel, 2011, among others), advancing an argument that to financial economists appears indisputable (Conrad and Loch, 2011): macroeconomic fluctuations are not only a product of the current situation in an economy but are very frequently influenced by agents' expectations of future developments.

Expectation indicators developed from opinion polls, whether carried out among business people, consumers or experts, are now widely used for essentially two purposes: to explore the mechanisms whereby expectations are formed and to ascertain their predictive power. In their extensive review of this empirical literature, Pesaran and Weale (2006) show that a number of different approaches have been used to address many of these issues.

Those who have engaged with the subject, chiefly for the purpose of identifying and predicting changes in cyclical fluctuations, include Svensson (1997), Berk (1999), Pesaran, Pierse and Lee (1993), Rahiala and Teräsvirta (1993), Smith and McAleer (1995), Kauppi, Lassila and Teräsvirta (1996), Öller (1990), Hanssens and Vanden Abeele (1987) and Alfarano and Milakovic (2010).

Authors such as Eusepi and Preston (2008), meanwhile, have shown the potential of disaggregated analysis for research into the genesis of cyclical fluctuations, focusing on the role of information disparities between agents linked by the production chain. Others (Long and Plosser, 1983; Blanchard, 1987; Durlauf, 1991; Caballero and Lyons, 1990) have emphasized various mechanisms whereby sectoral interactions in the formation of expectations - such as the build-up of small menu costs, disjointed decision-making and coordination failures-influence macroeconomic dynamics.

Although there is an extensive empirical literature on other economies, little research has been done on the subject in Uruguay. Because it is a small, open country, its economy has traditionally been subject to external shocks, particularly from its neighbours Argentina and Brazil. Those shocks have resulted in strong cyclical fluctuations and episodes of crisis, the last of which took place in the early 2000s. Despite this, only one study (Lanzilotta, 2006) is known to have addressed the role of expectations in generating economic fluctuations. That study revealed the influence of business expectations on overall economic activity, showing that the information they provided could be useful for predicting and anticipating cyclical fluctuations in Uruguay.

This paper follows on from Lanzilotta (2006), taking a predominantly empirical and exploratory approach. It examines the influence of Uruguayan industrialists' expectations on their own long-run performance, breaking down the sector into four groupings differentiated by their trade participation and production specialization. To investigate the relationship between the expectations of these four industry groupings and the spread of shocks between them, a dual procedure is followed, consisting of a long-run approach based on a cointegration analysis of expectations in the groupings, employing the procedure proposed by Johansen (1995) and Johansen and Juselius (1989), and the identification of common underlying trends through the estimation of multivariate structural time series models (Engle and Kozicki, 1993; Vahid and Engle, 1993), supplemented by analysis of the dynamics of the short-run transmission of expectation shocks using a multisectoral vector autoregression (VAR) model.

The empirical analysis makes use of the expectation measurements collected by the Chamber of Industry of Uruguay (CIU) and industrial production indicators from the Monthly Survey of Manufacturing Industry conducted by the National Institute of Statistics (INE). Monthly data from January 1998 to July 2011 are considered.

The findings show that the trend of industrialists' expectations tends to be tracked by sectoral production. In the most trade-oriented industry groupings the relationship is one of predetermination, showing how useful these indicators are for predicting growth in the sector. This common trend is identified with the one guiding the evolution of expectations in the export-oriented grouping, and expectations in the other groupings all depend on it to some degree. Lastly, impulse-response simulations derived from a multisectoral VAR model confirm the important role of the industries most exposed to international competition in spreading shocks in the short term. 
This document is organized as follows. Sections II and III outline the conceptual approach and methodology, respectively. Section IV discusses the advantages and drawbacks of using expectation indicators compiled from surveys (on which the empirical analysis is based). Section
$\mathrm{V}$ presents the data and the proposed industry breakdown. Section VI characterizes the industry groupings defined previously. Section VII presents the findings (empirical evidence), and conclusions are drawn in Section VIII. There are two annexes.

\section{II}

\section{Expectations and production dynamics}

The process whereby expectations are formed has been a key element in the study of economic problems in which agents must predict unknown variables.

Much of the most recent empirical research on expectations has refocused on the possibility that they may be a relevant factor in explaining business cycles. Authors such as Beaudry and Portier (2006) have found that in the United States economy, share prices are predictors of total factor productivity growth and financial booms are accompanied by a broad economic expansion. Karnizova (2010) has put forward a model to explain fluctuations caused by expectations, incorporating what she calls the intrinsic desire for wealth accumulation. Other authors (Eusepi and Preston, 2008) have developed a theory of fluctuations driven by expectations based on learning, with agents possessing incomplete information. Using a neoclassical model, Floden (2007) has shown that excessive optimism about future productivity can lead to immediate economic expansions (on the assumption of variable capacity utilization). Li and Mehkari (2009) have presented a model incorporating endogenous product creation, and Patel (2011) has studied the effect of investors' expectations on their investment decisions, finding that they are particularly important in contexts of poor-quality or limited information on assets.

Several studies with different approaches have stressed the importance of sectoral interactions in the transmission of shocks over time. In the literature on real business cycles, the importance of sectoral interactions is linked, for example, to the possibility that various types of agents, with rational expectations and interrelationships in the production chain, may have differing information, with this being reflected in dynamic responses to shocks affecting the economy. From another perspective, there has been discussion of the role of sectoral interactions and their influence on macroeconomic dynamics through mechanisms such as cost adjustments resulting from factors that may include the cumulative effects of small menu costs at the individual level, disjointed and unsynchronized decision-making and coordination failures. For example, Long and Plosser (1983) have analysed the spread of shocks between sectors via the production and use of intermediate inputs, Gordon (1981) and Blanchard (1987) have suggested that decisions taken in an industrial sector are influenced by price or production signals in other sectors located up- or downstream in the production chain, while Durlauf (1991) and Caballero and Lyons (1990) have shown how sectors influence one another through technological complementarities.

Beaudry and Portier (2007) argue that although expectations are often singled out as a factor that helps explain fluctuations, interactions can only be observed from a disaggregated sectoral analysis, i.e., a more detailed representation of the economy than macroeconomic models can provide. This influence arises because of production complementarities between the various sectors of the economy.

Lee and Shields (2000) elaborated on previous work by Lee and Pesaran (1994), Lee (1994) and Lee, Pesaran and Pierse (1992) to develop an intersectoral vAR model for industrial production in the United Kingdom which uses direct measurements of expectations (gathered by the Confederation of British Industry). The authors found that these data provided invaluable information on the role of expectations and could be used to identify the sources of persistent effects from shocks and the mechanisms whereby these effects were transmitted across sectors and over time.

This paper analyses the importance of business expectations in predicting industrial production, on the basis of previous studies for Uruguay (Lanzilotta, 2006) showing that these are a valuable input for a leading indicator of overall activity. Breaking industry down into broad groupings reveals some aspects of the interplay between expectations and production that would not otherwise come to light (Beaudry and Portier, 2007; Eusepi and Preston, 2008). 


\section{III}

\section{The methodological framework}

The methodology used by Lee and Shields (2000), which is based on econometric VAR methods, and the cointegration approach proposed by Johansen (1995) have been adopted to study interactions in the formation of expectations and those between expectations and the level of output in each industry grouping.

Impulse-response functions derived from the models estimated are analysed in all these cases. These functions, calculated from the reduced-form VAR errors, represent the combined effect of all the primary shocks that might affect a variable. As Stock and Watson (2001) point out, given that the endogenous variables in VAR models are usually correlated, so too are the error terms of the different reduced-form VAR equations.

Recursive model estimation has been one way to solve the problem of error correlation in VAR models. This methodology yields residuals that are intercorrelated between equations, so that the impulse-response function is calculated using impulses that are mutually orthogonal. The results will depend on the order in which the variables have been incorporated into the VAR, so that changing this order can yield different results. The order of the variables should not therefore be left to chance. The criterion followed here will be the one established by Litterman (1980), who ordered the variables by their degree of exogeneity (from most to least exogenous). This is a widely used process which consists in attributing the entire effect of any common component to the variable first specified in the VAR model. Operationally, it means that variables should be sorted from highest to lowest relative exogeneity.

Lastly, common trends among expectations are identified by estimating multivariate structural models, following Engle and Kozicki (1993) and Vahid and Engle (1993). Annex I describes the econometric methods applied.

\section{IV}

\section{Indicators of expectations}

The use of indicators that represent agents' expectations as ascertained from surveys is widespread in countries with advanced statistical systems. The latest global economic crisis has shown the need for timely economic data and the difficulty of anticipating the future. The fact that opinion poll data become available fairly swiftly, usually in advance of official quantitative statistics, means they have enormous potential for decision-makers seeking to analyse the economic outlook (Remond-Tiedrez, 2005). Timeliness is an important dimension of the quality of statistical information, and data from surveys of business and consumer expectations usually possess this.

Indicators of expectations have been widely used in the applied literature to capture and anticipate movements in an array of variables, such as interest rates, unemployment and prices, and to shed light on the formation of expectations and business planning. The questions that empirical studies on expectations seek to answer include: (i) What is the nature of expectations? (ii) How are they formed and to what extent do people learn from experience? (iii) What is the relationship between the standard assumptions of economic theory and the formation of expectations in practice? (iv) How much can data on expectations improve the performance of conventional prediction methods? For a review of this literature, see Pesaran and Weale (2006).

The empirical literature contains numerous examples where the object of study is statistics on expectations and their usefulness for predicting and detecting changes in cyclical fluctuations. Svensson (1997) and Berk (1999) examined the measurement of expected inflation, while Pesaran, Pierse and Lee (1993), Rahiala and Teräsvirta (1993), Smith and McAleer (1995), Kauppi, Lassila and Teräsvirta (1996), Öller (1990) and Hanssens and Vanden Abeele (1987) focused on production growth, and Batchelor (1982) considered employment. Authors such as Batchelor (1982), Smith and McAleer (1995) and Alfarano and Milakovic (2010) have explored the use of data from opinion polls as indicators of business behaviour to test different models for the formation of expectations or interactions among agents. 
These studies have served to identify a set of problems with the processing and interpretation of data from opinion polls which cast doubt on whether these data are a suitable proxy for agents' actual expectations. One of the most significant studies (Chan-Lee, 1980) argues that opinion poll results are sensitive to errors in sampling and the wording of questions. Another of the most serious criticisms is that respondents may express opinions different from those that ultimately guide their actions and may try to manipulate their responses strategically in order to bring about the result they want (Nardo, 2003). Another problem pointed out by Nardo is framing, which may also introduce biases into responses.

In their review of the literature on the use of expectations data, Pesaran and Weale (2006) stress two crucial aspects: the way responses are gathered and the way they are converted into aggregate quantitative data. This paper has attempted to deal with both aspects.

The information on business expectations used here comes from the monthly industrial surveys conducted by the CIU since 1997. In addition to collating sales figures, this survey looks at expectations about the future performance of the company's own business, foreign and domestic markets, the branch of industrial activity in which the company operates (industry sector) and the economy as a whole. Indicators of expectations studied in this paper concern the two last (expectations about the sector and about the national economy). Given that both the CIU and the INE collect sales information, the representativeness of the cIU survey can be ascertained by comparing the two series. The good fit between the CIU sales series and the official one provides reassurance that there are no serious sampling errors. Nonetheless, mismatches between the views expressed by industrialists and their true expectations (owing to problems of framing or strategic bias, for example) could in principle be an issue.

A second aspect to be considered is the method of aggregation. In the monthly CIU survey, respondents

\section{V}

\section{The data}

In addition to the indicators of expectations discussed above, this paper also considers industrial production data from the INE physical volume index (PVI) for manufacturing industry (Monthly Survey of Manufacturing Industry, base year 2006). Production at the State from each company are asked the following question: "In view of the current situation, how do you expect the national economy, your sector and your company to perform in the next six months?" They are asked to state whether they expect the situation (in each of the three dimensions) to improve, worsen or remain the same. The balance statistic method is used to aggregate these responses. This procedure is employed by Eurostat and is routinely used in applied studies on the subject, among the most recent being Kangasniemi, Kangassalo and Takala (2010) and Kangasniemi and Takala (2012). This methodology involves the construction of aggregate indicators of expectations by subtracting the number of negative responses from the number of positive responses then dividing by the total number of responses. Each response is accorded equal weight in the indicator regardless of the size of the company or the branch of activity in which it operates.

Internationally, few attempts have been made in the literature to compare the different quantification methods in a simulation context. One such effort was made by Common (1985), who concluded that no specific method appeared to be preferable to another. Nardo (2003) and Nardo and Cabeza-Gutés (1999) found that the method performed moderately well, although their conclusions depended on the process chosen to produce the data for their simulations.

Lastly, a further point needs to be made about the characteristics of expectation indicators. By construction, the balance statistic limits quantitative indicators of expectations to within a range of $[-1,1]$. A value of -1 is produced in the hypothetical case that all respondents expect the situation to worsen, and 1 if they all expect it to improve. This means that the indicator cannot theoretically worsen once it reaches -1 or improve once it attains the maximum of 1 , which could be restrictive in terms of capturing the expectations of industrialists. However, none of the expectation indicators in the sample analysed here came anywhere near the extremes at any point in the period. oil refinery is not included in the index, and this division of industry is accordingly excluded from all the results. The data analysed in this study concern the period from January 1998 to July 2011 and are monthly. 
Given the small size of the databases available, which made it impossible to analyse industry by division, the decision was taken to break industry down into groupings for multisectoral modelling purposes.

The criterion for grouping branches of industry was that applied by Laens and Osimani (2000), who disaggregate industry by patterns of trade and production specialization, considering import and export flows and domestic production of goods in the branch of industry concerned. ${ }^{1}$ This disaggregation criterion ensures that growth determinants act in a reasonably homogeneous way within each group. As Lorenzo, Lanzilotta and Sueiro (2003) state, breaking industry down into

1 These authors classify 73 industrial sectors (disaggregated at the four-digit level of the International Standard Industrial Classification of all Economic Activities (ISIC revision 2)) into four groupings: export industries, low-trade industries, import-substitution industries and intra-branch trade industries. First, sectors with an openness ratio (exports plus imports as a share of overall output) of under 5\% are separated out and placed in the low-trade grouping. Sectors with an openness ratio of over 5\% are then analysed for intra-industry trade using the relevant Grubel-Lloyd indices. Branches of industry with a Grubel-Lloyd index value of over 0.50 are placed in a second grouping, intra-industry trade. Those with Grubel-Lloyd scores of less than 0.50 are then separated according to whether their sectoral trade balance is positive or negative, sectors with a positive trade balance being classed as exporters and those with a negative balance as import-substitution industries. homogeneous groupings enhances the diagnosis since sectoral specificities are manifested in clearly differentiated patterns of behaviour.

Production variables are log-transformed and are expressed as $p v i \_i$, with $i$ being the industry grouping: export industries $(x)$, import-substitution industries $(m)$, intra-branch trade industries (it) or low-trade industries $(l t)$. Similarly, indicators of expectations about the economy are expressed as iec_i and those of expectations about the sector as isec_i. All variables are shown in figure 1 .

The conclusion from statistical analysis of the production and expectations series for each of the industry groupings is that they are all integrated of order 1 (I(1)) (see table A.1 in the econometric annex). The analysis applied the augmented Dickey-Fuller (ADF) test and the Kwiatkowski-Phillips-Schmidt-Shin (KPSS) stationarity test. In the ADF test, the null hypothesis holds that the process is integrated in the first order and this hypothesis is accepted unless there is clear evidence to the contrary, whereas in the KPSS test the null hypothesis is stationarity. This complements the ADF test, which has low power against stationarity when there are near-unit root processes.

Expectation variables behave like random walks with drift. The PVI industrial series for groupings $m$, it and $l t$ present a markedly seasonal pattern, so a seasonal difference was applied in these cases.

FIGURE 1

Physical volume index (PVI) and indicators of expectations about the economy (IEC) and industry groups' own sector (ISEC), January 1998 to July 2011

(Physical volume index values in logarithms from index with base 100 in 2006, index of expectations)

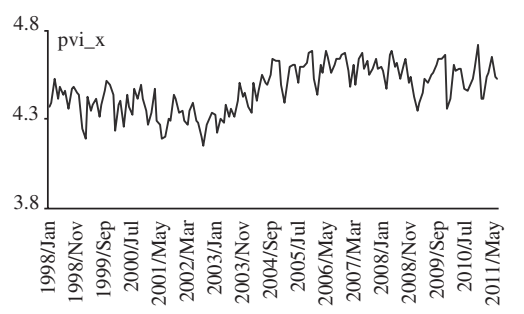

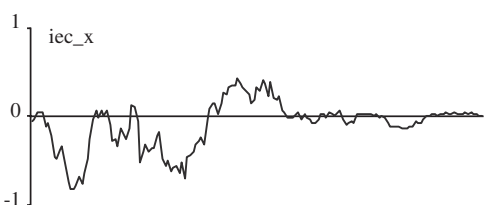

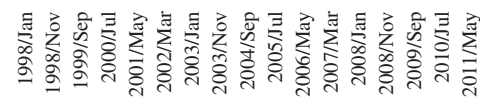

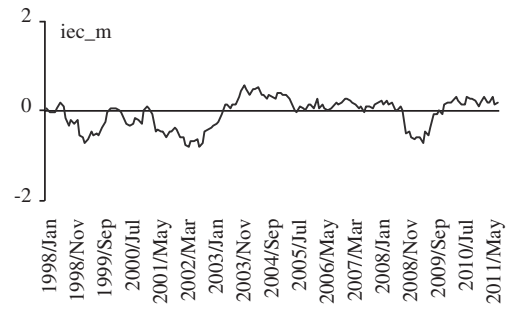

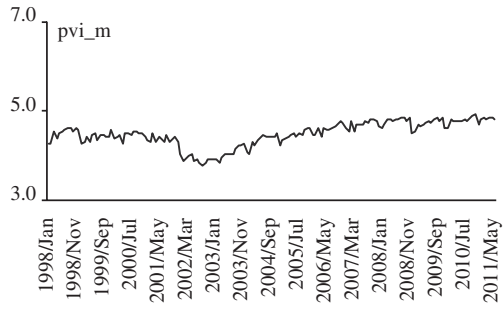

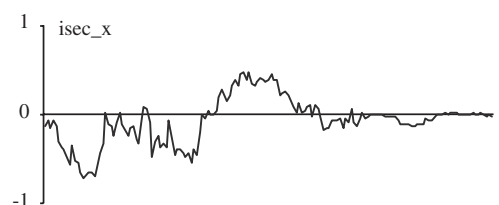
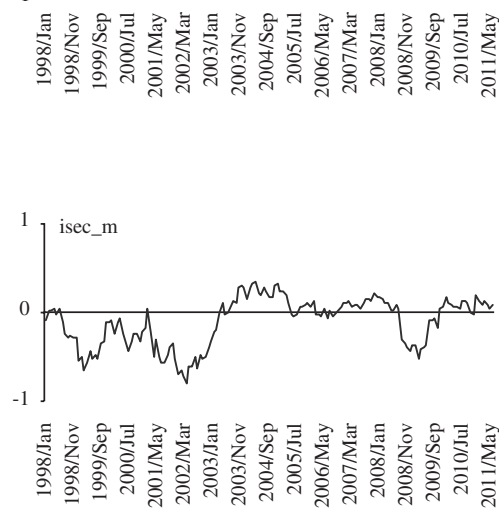

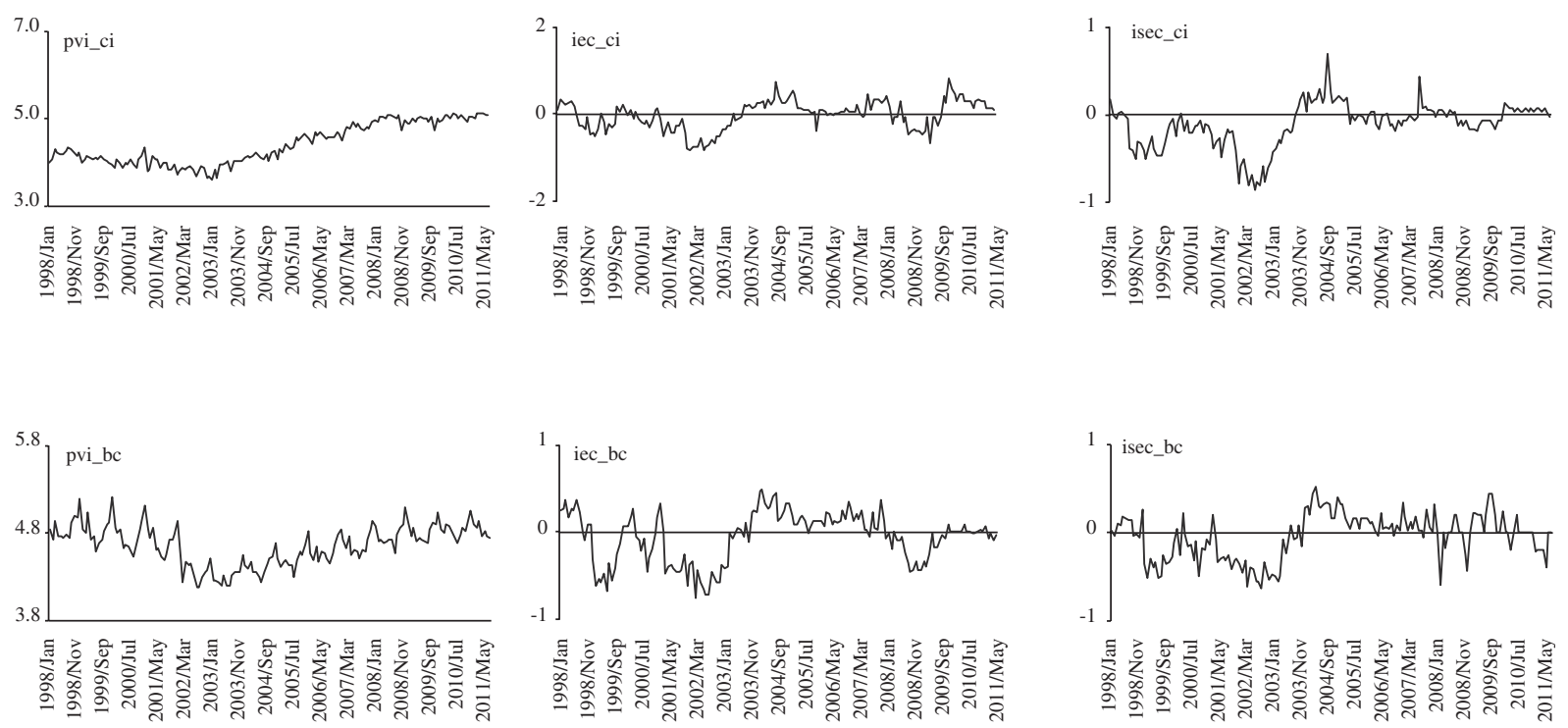

Source: prepared by the author on the basis of data from the Uruguayan National Institute of Statistics (INE) and the Chamber of Industry of Uruguay (CIU).

\section{VI}

\section{Brief characterization of the groupings}

Uruguay's manufacturing industry, which is predominantly trade-oriented, accounted for an average of about $15 \%$ of the economy's gross domestic product (GDP) and a little over $23 \%$ of its gross value of production (GVP) in the period under study. Against that background, a brief characterization of the four groupings is provided here to give an initial idea of the key factors that motivate business behaviour as regards expectations and the way these factors interact. Table 1 shows each grouping's share of GVP and gross value added (GVA) in the manufacturing sector for two selected years, 1997 and 2007, taken from near the beginning and end of the sample analysed. ${ }^{2}$

The export industries grouping makes the greatest contribution to total industrial GVP and GVA (46\% and $34 \%$, respectively), while import-substitution industries are responsible for over a quarter of both. Between 1997

21997 is the earliest year available with the disaggregation needed to construct the groupings. and 2007, the low-trade industries grouping lost some of its share of overall production to intra-branch trade industries. The latter group and import-substitution industries accounted for over a quarter of total manufacturing GVP at the end of the period.

Production structures are presented in table 2. Although intermediate consumption trended upward over the period across almost all the groupings (the exception being intra-branch trade), the actual quantities involved are one of the characteristics that differentiate them. The volume of inputs, and particularly domestic inputs, used in production gives an idea of potential productive linkages between groupings. It also provides a lead to the possible multiplier effects of a particular grouping in the sector as a whole.

The export industries grouping presents the lowest proportion of value added in its GVP. Over half its intermediate consumption is in the form of purchases of raw materials, chiefly domestically sourced agricultural 


\begin{tabular}{|c|c|c|c|c|}
\hline \multirow{2}{*}{ Grouping } & \multicolumn{2}{|c|}{1997} & \multicolumn{2}{|c|}{2007} \\
\hline & GVP & GVA & GVP & GVA \\
\hline Export & 51.0 & 38.0 & 45.9 & 34.0 \\
\hline Import-substitution & 20.0 & 27.0 & 27.7 & 26.4 \\
\hline Intra-branch trade & 10.0 & 10.0 & 17.0 & 26.0 \\
\hline Low-trade & 19.0 & 25.0 & 9.4 & 13.6 \\
\hline Industry total ${ }^{\mathrm{a}}$ & 100.0 & 100.0 & 100.0 & 100.0 \\
\hline
\end{tabular}

Source: prepared by the author on the basis of the National Institute of Statistics (INE) 1997 Annual Survey of Industry (EIA) and 2007 Survey of Economic Activity (EAE).

a Excluding oil refinery.

Note: GVP: gross value of production. GVA: gross value added.

TABLE 2

Production structure by industry grouping, 1997 and 2007

(Percentages)

\begin{tabular}{|c|c|c|c|c|c|c|}
\hline \multirow{2}{*}{ Grouping } & \multicolumn{3}{|c|}{1997} & \multicolumn{3}{|c|}{2007} \\
\hline & GVA & Intermediate consumption & GVP & GVA & Intermediate consumption & GVP \\
\hline Export & 27.2 & 72.8 & 100.0 & 21.7 & 78.3 & 100.0 \\
\hline Import-substitution & 50.5 & 49.5 & 100.0 & 28.0 & 72.0 & 100.0 \\
\hline Intra-branch trade & 38.1 & 61.9 & 100.0 & 44.7 & 55.3 & 100.0 \\
\hline Low trade & 50.9 & 49.1 & 100.0 & 42.8 & 57.2 & 100.0 \\
\hline
\end{tabular}

Source: National Institute of Statistics (INE), 1997 Annual Survey of Industry (EIA) and 2007 Survey of Economic Activity (EAE).

Note: no disaggregated data on intermediate consumption are available for 2007. GVA: gross value added. GVP: gross value of production.

products. ${ }^{3}$ Import-substitution industries had a structure similar to that of exporters in the later period (although their composition was initially balanced between value added and inputs). However, unlike the exporters, the import-substitution industries are characterized by having a high share of inputs from abroad. The low-trade and intra-branch trade industries had a higher ratio of value added to GVP than the other two groupings in 2007. Domestic raw materials were a preponderant share of inputs in both cases, at least at the beginning of the period (the only time for which data are available).

It is important to note that of the four groupings, the export and import-substitution industries are the most exposed to international competition, the former because of the markets they trade in, particularly when they are international, and the latter because of foreign competition for products they sell mainly in the domestic

\footnotetext{
${ }^{3}$ Information available for 1997 only.
}

market (although also to MERCOSUR) and the cost of the inputs they use, which are chiefly imported.

In intra-branch trade industries, trade and competition take place within the branch itself. The main destination market for goods produced by this grouping is MERCOSUR, especially Argentina. The main destination for goods from low-trade industries is, by definition, the domestic market. Some branches within this group may, however, be indirectly linked to the foreign market by dint of supplying inputs to industries that export to the region or the wider world. ${ }^{4}$ Although inputs account for a smaller share of the production structure in these latter two groupings than in the other two, productive linkages with other industrial and non-industrial sectors via the supply of local inputs are growing in importance.

\footnotetext{
${ }^{4}$ In fact, some branches in this grouping (manufacture of soft drinks and tobacco) are indirectly affected by international competition owing to the informal trade in illegally imported products.
} 


\section{VII}

\section{Empirical evidence}

The empirical research focused on identifying interactions between sectoral expectations and production growth (see section II). Sectoral interdependence in long-term expectations - or, what comes to the same thing, the existence of common underlying trends between expectations in the four industry groupings - was also examined (see sections III and IV). Lastly (see section V), short-term interactions between expectations and production are presented as part of a multisectoral VAR model.

\section{Expectations and industrial production}

Firstly, it was ascertained whether equilibrium relationships existed between expectations and industrial production in each grouping, with a view to determining whether there was a common underlying trend linking industrial performance and industrialists' perceptions of the future of the economy and their sector.
In all cases, expectations and the level of industrial production in each grouping were found to follow a common long-term trend. The Johansen test showed that there was a positive relationship in the long term between year-on-year production growth in the sector and sectoral expectations about the economy and the sector itself. Table 3 presents the relationships arrived at by estimating the vector error correction model. ${ }^{5}$

The size of the coefficients shows that industrialists' perceptions of the future performance of their own sector have a greater effect on sectoral production than do expectations about the economy at large. In the intrabranch trade and low-trade industry groupings, sectoral expectations and production are mutually determining.

${ }^{5}$ The full estimates are available from the author on request.

TABLE 3

\section{Cointegrating relationships between expectations and industrial production}

\begin{tabular}{|c|c|c|c|c|}
\hline Unrestricted estimates & & $\begin{array}{l}\text { (Weakly) } \\
\text { exogenous } \\
\text { variable }\end{array}$ & $\begin{array}{c}\text { Endogenous variables: } \\
\text { error correction } \\
\text { mechanism (ECM) } \\
\text { coefficient }\end{array}$ & $\begin{array}{l}\text { Restrictions (specification } \\
\text { and test statistic) }\end{array}$ \\
\hline \multicolumn{5}{|c|}{ Expectations about the performance of the economy } \\
\hline $\begin{array}{l}\text { Equation } 1 \\
\left(\operatorname{ECM}\left[\Delta_{12} p v i \_x, i e c \_x\right]\right)\end{array}$ & $\begin{array}{c}\Delta_{12} p v i \_x=0.024+0.213 * i e c \_x \\
(0.015)(0.064)\end{array}$ & $i e c \_x$ & $\alpha\left(\Delta_{12} p v i \_x\right)=-0.662$ & $\begin{array}{c}\beta\left(\Delta_{12} p v i \_x\right)=1 ; \alpha\left(i e c \_x\right)=0 ; \\
\chi^{2}=3.461, \text { pr. }=0.063\end{array}$ \\
\hline $\begin{array}{l}\text { Equation } 2 \\
\left(\operatorname{ECM}\left[\Delta_{12} p v i \_m, i e c \_m\right]\right)\end{array}$ & $\begin{array}{c}\Delta_{12} p v i \_m=0.005+0.452 * i e c \_m \\
(0.003)(0.092)\end{array}$ & $i e c \_m$ & $\alpha\left(\Delta_{12} p v i \_m\right)=-0.330$ & $\begin{array}{c}\beta\left(\Delta_{12} p v i \_m\right)=1 ; \alpha\left(i e c \_m\right)=0 \\
\chi^{2}=3.732, \text { pr. }=0.053\end{array}$ \\
\hline $\begin{array}{l}\text { Equation } 3 \\
\left(\operatorname{ECM}\left[\Delta_{12} p v i \_i t, i e c \_i t\right]\right)\end{array}$ & $\begin{array}{c}\Delta_{12} p v i \_i t=0.107+0.442 * i e c \_i t \\
(0.002)(0.071)\end{array}$ & & \multicolumn{2}{|c|}{$\alpha\left(\Delta_{12} p v i \_i t\right)=-0.470, \alpha\left(i e c \_i t\right)=0.338$} \\
\hline $\begin{array}{l}\text { Equation } 4 \\
\left(\operatorname{ECM}\left[\Delta_{12} p v i \_l t, i e c \_l t\right]\right)\end{array}$ & $\begin{array}{c}\Delta_{12} p v i \_l t=0.225+0.385 * i e c \_l t \\
(1.071)(0.083)\end{array}$ & $i e c \_l t$ & $\alpha\left(\Delta_{12} p v i \_l t\right)=-0.404$ & $\begin{array}{c}\beta\left(\Delta_{12} p v i \_l t\right)=1 ; \alpha\left(i e c \_l t\right)=0 ; \\
\chi^{2}=2.631, \text { pr. }=0.105\end{array}$ \\
\hline \multicolumn{5}{|c|}{ Expectations about the performance of the economy } \\
\hline $\begin{array}{l}\text { Equation } 5 \\
\left(\operatorname{ECM}\left[\Delta_{12} p v i \_x, i s e c \_x\right]\right)\end{array}$ & $\begin{array}{c}\Delta_{12} p v i \_x=0.014+0.272 * i s e c \_x \\
(0.013)(0.063)\end{array}$ & $i s e c \_x$ & $\alpha\left(\Delta_{12} p v i_{-} x\right)=-0.714$ & $\begin{array}{c}\beta\left(\Delta_{12} p v i \_x\right)=1 ; \alpha\left(i s e c \_x\right)=0 \\
\chi^{2}=0.210, \text { pr. }=0.646\end{array}$ \\
\hline $\begin{array}{l}\text { Equation } 6 \\
\left(\operatorname{ECM}\left[\Delta_{12} p v i \_m, i s e c \_m\right]\right)\end{array}$ & $\begin{array}{c}\Delta_{12} p v i \_m=0.058+0.519 * i s e c \_m \\
(0.022)(0.083)\end{array}$ & $i s e c \_m$ & $\alpha\left(\Delta_{12} p v i \_m\right)=-0.457$ & $\begin{array}{c}\beta\left(\Delta_{12} p v i \_m\right)=1 ; \alpha(\text { isec_m } m)=0 ; \\
\chi^{2}=0.204, \text { pr. }=0.651\end{array}$ \\
\hline $\begin{array}{l}\text { Equation } 7 \\
\left(\mathrm{ECM}\left[\Delta_{12} p v i \_i t, i e c \_i t\right]\right)\end{array}$ & $\begin{array}{c}\Delta_{12} p v i \_i t=0.157+0.635^{*} i s e c \_i t \\
(0.041)(0.158)\end{array}$ & & \multicolumn{2}{|c|}{$\alpha\left(\Delta_{12} p v i \_i t\right)=-0.342, \alpha\left(i e c \_i t\right)=0.143$} \\
\hline $\begin{array}{l}\text { Equation } 8 \\
\left(\mathrm{ECM}\left[\Delta_{12} p v i \_l t, i e c \_l t\right]\right)\end{array}$ & $\begin{array}{c}\Delta_{12} p v i \_l t=0.006+0.589 * i s e c \_l t \\
(0.014)(0.057)\end{array}$ & & \multicolumn{2}{|c|}{$\alpha\left(\Delta_{12} p v i \_l t\right)=-0.423, \alpha\left(i e c \_l t\right)=0.671$} \\
\hline
\end{tabular}

Source: prepared by the author.

$\Delta_{12}$ : twelfth difference.

ECM: error-correction mechanism coefficient. 
In the export and import-substitution groupings, the hypothesis that sectoral expectations are weakly exogenous cannot be rejected (at 5\%). This would mean that in these two groupings, unlike the others, there was no feedback between their own performance and their perceptions of the future. Expectations about the economy, meanwhile, have an exogenous effect for all industry groupings except intra-branch trade.

The impulse-response analysis presented in figure 2 shows the dynamic reactions of industrial output to

FIGURE 2

Impulse-response simulations, equations 1 to 8

(Shock simulated: 1 standard deviation; 36 periods)
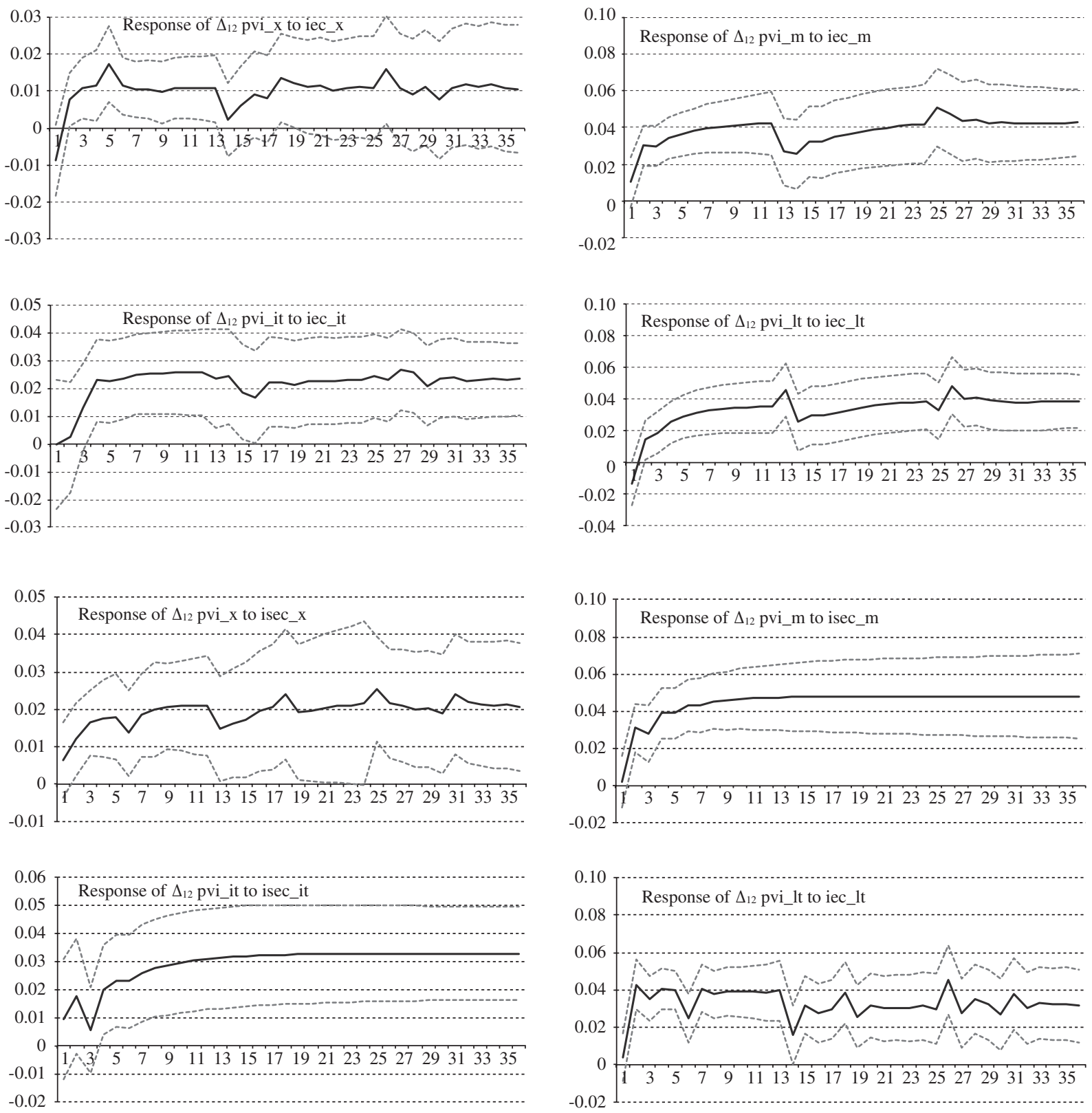

Source: prepared by the author.

Note: confidence intervals are standard errors calculated using Monte Carlo simulations (with 1,000 repetitions).

$\Delta_{12}$ : twelfth difference. 
expectation shocks. ${ }^{6}$ These simulations reveal both the magnitude of the impact and the time needed to absorb it. What emerges from the simulations is that responses to expectation shocks are not usually instantaneous, although they are rapid, with no more than three or four quarters being required for the whole effect to be absorbed. ${ }^{7}$

The results of the cointegration analysis, the weak exogeneity tests (table 3) and the strong exogeneity tests (see the Granger test in table A.5 of annex I) show that the expectations of export and import-substitution industrialists contain information of relevance for predicting and anticipating their production performance. The intuition behind this is simple. Industrialists have a wealth of information on the economic environment directly affecting their business and can therefore perceive deteriorations or improvements in economic prospects before production falls or rises. What is more, their own optimism or pessimism can influence

${ }^{6}$ In all cases, the size of the shock simulated is one standard deviation.

7 The variables were ordered by their degree of exogeneity. However, the robustness of the results was checked against other specifications (by reordering the variables) and no significant alteration was seen in the responses. variables such as investment and decisions about stocks, employment and other variables that go to determine their level of production. This serves to corroborate at a sectoral level the results of previous studies showing expectations to be a useful leading indicator for the cycle of economic activity in Uruguay (Lanzilotta, 2006).

\section{Sectoral interdependence in the formation of expectations}

The second phase of the research focused on determining the role played by sectoral interrelationships in forming expectations in the four groups. More specifically, it aimed to ascertain whether expectations in the four groups (represented in figure 3) followed a common long-term trajectory.

With this in view, the existence of cointegrating relationships between expectations in the four groupings was investigated and, where these were found to exist, vector error correction models were estimated to determine how exogenous the indicators were. The relationships determined are presented in table 4 .

The results show that there are (three) long-term linear relationships between the four industry groupings'

FIGURE 3

\section{Expectations about the economy, January 1998 to July 2011} (Index values)

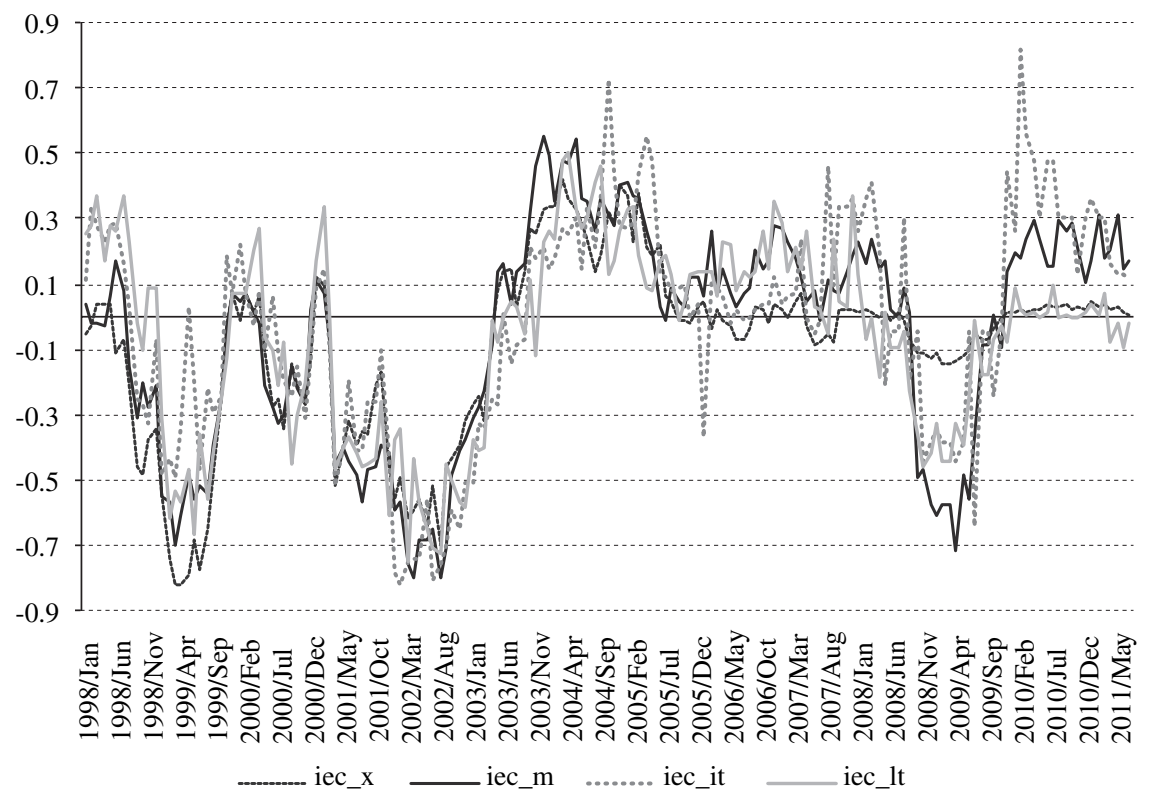

Source: prepared by the author on the basis of data from the Chamber of Industry of Uruguay (cIU).

Note: $i e c \_i$ : expectations about the economy; $i e c \_x$ : expectations about export industries; iec_m: expectations about import-substitution industries; iec_it: expectations about intra-branch trade industries; $i e c \_l t$ : expectations about low-trade industries. 
TABLE 4

\section{Long-term equations between expectations about the economy}

\begin{tabular}{|c|c|c|c|c|}
\hline \multicolumn{2}{|c|}{$\begin{array}{l}\text { Error-correction mechanism (ECM) coefficient }\left[i e c \_x \text {, }\right. \\
i e c \_m \text {, iec_it, iec_lt], three cointegrating relationships } \\
\text { (restricted estimates) }\end{array}$} & \multirow{2}{*}{$\begin{array}{l}\text { (Weakly) } \\
\text { exogenous } \\
\text { variable } \\
\text { iec_x }\end{array}$} & \multirow{2}{*}{$\begin{array}{c}\text { Endogenous variable: } \\
\text { error-correction } \\
\text { mechanism (ECM) } \\
\text { coefficient }\end{array}$} & Constraints \\
\hline Equation 9 & $\begin{array}{c}i e c \_m=0.056+i e c \_x \\
(0.053)\end{array}$ & & & $\begin{array}{l}\beta\left(i e c \_x\right)=\beta\left(i e c \_m\right)=1 \\
\beta\left(i e c \_i t\right)=\beta\left(i e c \_l t\right)=0 \\
\alpha\left(i e c \_x\right)=\alpha\left(i e c \_i t\right)=\alpha\left(i e c \_l t\right)=0\end{array}$ \\
\hline Equation 11 & $\begin{array}{c}i e c_{-} l t=0.025+i e c \_x \\
(0.043)\end{array}$ & $i e c \_x$ & -0.223 & $\begin{array}{l}\beta\left(i e c \_x\right)=\beta\left(i e c \_l t\right)=1 \\
\beta\left(i e c \_i t\right)=\beta\left(i e c \_m\right)=0 \\
\alpha\left(i e c \_x\right)=\alpha\left(i e c \_i t\right)=\alpha\left(i e c \_m\right)=0\end{array}$ \\
\hline
\end{tabular}

Joint restriction test: $\chi(12)=20.8962321$

Probability $=0.051921$

Source: prepared by the author.

Note: iec_x: expectations about export industries; iec_m: expectations about import-substitution industries; iec_it: expectations about intrabranch trade industries; iec_lt: expectations about low-trade industries.

expectations about the economy, with two groupings being involved in all relationships.

Two aspects should be stressed. First, the existence of three cointegrating relationships means that there is only one single common long-term trajectory underlying the expectations of all four groupings. Second, the variables identified as (weakly) exogenous are the expectations of exporters and of import-substitution industries, with the former acting as determinants of the latter. This means that perceptions about the future of the economy in the industries most exposed to international competition (which probably have most access to information on the external context, something that is crucial for an economy as small and open as Uruguay's) appear ultimately to set the overall mood or stance of expectations in industry as a whole.

This evidence about the direction of determination of expectations between groups indicated the correct approach for the impulse-response simulations showing short-term dynamics in response to shocks (see the panels in figure 4$){ }^{8}$

\footnotetext{
${ }^{8}$ As noted earlier, for the impulse-response function to be calculated using mutually orthogonal impulses, it is necessary to obtain residuals that are uncorrelated between the VAR model equations. One possible method of orthogonalizing impulses is the one proposed by Cholesky, which involves using the inverse of the Cholesky factor of the residual covariance matrix to orthogonalize the impulses. This imposes an order on the variables in the VAR such that the full effect of any common component is attributed to the variable ranked first in the system. The variables should not therefore be ordered randomly but from most to least exogenous.
}

The simulations showed that:

(i) Shocks to the expectations of exporters have a significant and long-lasting positive impact on expectations in the other groupings. The effect is immediate and is fully absorbed in less than half a year.

(ii) Shocks to the expectations of import-substitution industries also affect the other groupings positively, but to a lesser degree. The greatest effect is on expectations in intra-branch trade industries.

(iii) Shocks to the expectations of intra-branch trade industries and those producing for the domestic market have no effect whatever on perceptions in the other groupings.

As for the relationship between sectoral expectations in the four groupings, no single common trajectory could be shown to exist. For this reason and with a view to exploring short-term interactions, a multisectoral VAR model was estimated (using stationarity-transformed variables). The results of the impulse-response simulations are presented in figure 5.

These simulations show that:

(i) Once more, a shock to exporters' expectations has a very significant effect on the other industry groupings. The effect on the latter's expectations is also rapid and is fully absorbed within six months.

(ii) A shock to import-substitution industries also has a significant spillover effect, although it is of lesser magnitude and is substantial for only two groupings: exporters and intra-branch trade industries. 
FIGURE 4

Impulse-response representations from the VECM model of expectations about the economy ${ }^{\mathrm{a}}$

(Shock simulated: 1 standard deviation; 24 periods)
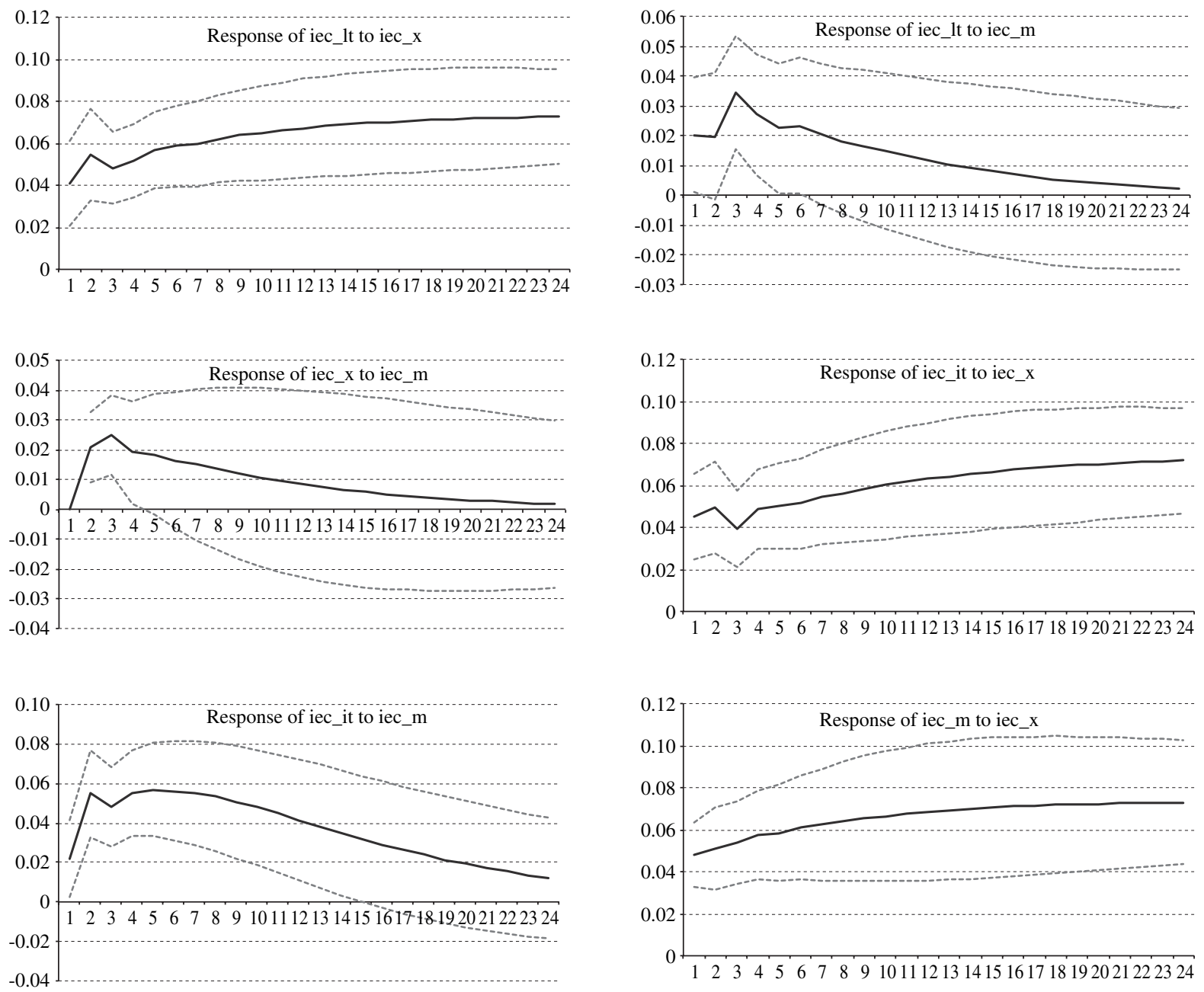

Source: prepared by the author.

a VECM: vector error correction model.

Note: only significant responses are reported. The order of the variables in the impulse definition was: iec_x,iec_m, iec_it, iec_lt . 
FIGURE 5

Impulse-response representations from the VAR model of sectoral expectations ${ }^{\mathrm{a}}$ (Shock simulated: 1 standard deviation; 24 periods)
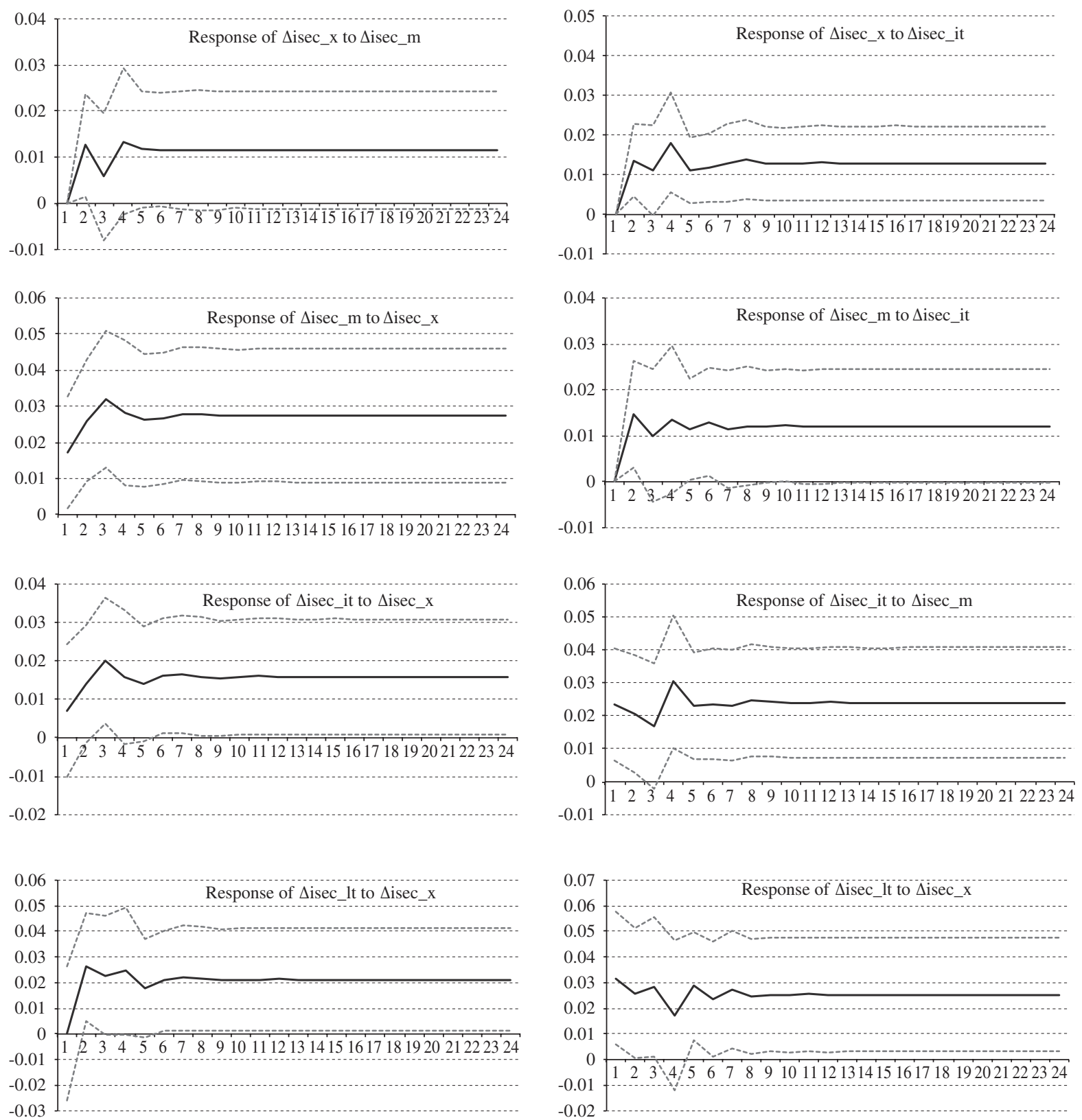

Source: prepared by the author.

a VAR: multisectoral vector autoregression model.

Note: only statistically significant impulse-response simulations are reported. Confidence intervals are standard errors calculated using Monte Carlo simulations (with 1,000 repetitions). Responses are cumulative. 
(iii) Shocks to the expectations of low-trade industries and intra-branch trade industries have no significant lasting effect on the other groupings.

\section{Common trends in expectations}

The evidence for a cointegrating relationship between the macroeconomic expectations of the four industry groupings suggests that expectations follow a single underlying trend in the long term. A multivariate structural model like the one in Section III is estimated to identify this trend, setting out from an unrestricted specification of a local oscillation relative to the variable of the level component (in accordance with the characteristics of the four series). The results are presented in table 5 .

The model's variance-covariance matrix shows a high degree of correlation between the levels of the expectations series (see table 6).

The high degree of correlation suggests the existence of common trends. At the same time, the eigenvalues of the variance-covariance matrix demonstrate that the matrix rank is 1 ( 2 at a lower significance level). This justified the restriction of common levels between the series (consistent with the findings of the previous section). In consideration of the eigenvalues of the matrix of variances and in accordance with the results of the cointegration analysis, the expectations series for intra-branch trade, low-trade and import-substitution industries were specified as dependent. The results are presented in table 7 and figure 6.9

The model estimated (ignoring cyclical and autoregressive components) can be written as:

$$
\begin{gathered}
i e c \_x_{t}=\mu_{t}^{*}+\varepsilon_{i e c x t}, \\
i e c \_m_{t}=1.334 \mu_{t}^{*}+0.05132+\varepsilon_{i e c m t}, \\
i e c \_i t_{t}=1.374 \mu_{t}^{*}+0.09907+\varepsilon_{i e c i t t}, \\
i e c \_l c_{t}=1.135 \mu_{t}^{*}+0.04753+\varepsilon_{\text {ieclct }},
\end{gathered}
$$

9 As an alternative, a test was carried out with a non-dependent specification for expectations in import-substitution industries.

TABLE 5

Unrestricted multivariate structural model. Vector of endogenous variables: $\left[i e c \_x \text {, iec_m, iec_it, iec_lt }\right]^{a}$

Model estimated:

$\mathrm{Y}=$ Level + Irregular + Cycle $+\mathrm{AR}(1)$ (strong convergence)

iec_x iec_m iec_it $\quad$ iec_lt

I. Standard deviations of the component residues:

\begin{tabular}{lcccc}
\hline Irregular & 0.0337925 & 0.02795049 & 0.09649927 & 0.00051 \\
Level & 0.0783388 & 0.00973299 & 0.015386 & 0.00000 \\
Cycle & 0.0324932 & 0.07674432 & - & 0.02451 \\
AR(1) & - & - & 0.06820286 & - \\
\hline II. Model diagnostic statistics: & & & & \\
\hline Residual standard error & 0.094989 & 0.11361 & 0.17006 & 0.13458 \\
Normality (Bowman-Shenton) & 35.033 & 14.921 & 16.476 & 8.4247
\end{tabular}

Source: prepared by the author.

${ }^{\text {a }} \mathrm{A}$ full list of outputs is available from the author on request.

Note: iec_x: expectations about export industries; iec_m: expectations about import-substitution industries; iec_it: expectations about intrabranch trade industries; iec_lt: expectations about low-trade industries.

$\mathrm{AR}(1)$ : autoregressive process (order $=1$ ).

TABLE 6

Variance-covariance matrix of the residuals

\begin{tabular}{lcccc}
\hline & $i e c \_x$ & $i e c \_m$ & $i e c \_i t$ & $i e c \_l t$ \\
\hline$i e c \_x$ & 0.006137 & 0.995000 & 0.952900 & 0.922100 \\
$i e c \_m$ & 0.007574 & 0.009441 & 0.973700 & 0.956000 \\
$i e c \_i t$ & 0.007036 & 0.008917 & 0.008883 & 0.969100 \\
iec_lt & 0.005938 & 0.007635 & 0.007508 & 0.006756 \\
\hline
\end{tabular}

Source: prepared by the author.

Note: $i e c \_x$ : expectations about export industries; $i e c \_m$ : expectations about import-substitution industries; iec_it: expectations about intrabranch trade industries; iec_lt: expectations about low-trade industries. Grey shading denotes significant values. 
TABLE 7

Multivariate structural model with common trends.

Vector of endogenous variables: [iec_x,iec_m, iec_it, iec_lt]

Model estimated:

$\mathrm{Y}=$ Level + Irregular + Cycle $+\mathrm{AR}(1)$ (strong convergence)

$i e c \_m$, iec_it and iec_lt: dependent

$i e c \_x \quad i e c \_m$ ie $i t \quad i e c \_l t$

\begin{tabular}{lcccc}
\hline I. Standard deviations of the component residues: & & & & \\
\hline Irregular & 0.0296749 & 0.02685736 & 0.10344999 & 0.00000 \\
Level & 0.0688404 & & 0.11564 \\
Cycle & 0.0545438 & 0.11828271 & 0.06102221 \\
AR(1) & & & & 0.17006 \\
\hline II. Model diagnostic statistics: & 0.094989 & 0.11361 & 0.13458 \\
Residual standard error & 35.033 & 14.921 & 16.476 & 8.4247 \\
Normality (Bowman-Shenton) & & & &
\end{tabular}

Source: prepared by the author.

Note: iec_x: expectations about export industries; $i e c \_m$ : expectations about import-substitution industries; iec_it: expectations about intrabranch trade industries; iec_lt: expectations about low-trade industries. AR(1): autoregressive process (order = 1).

FIGURE 6

Components of the multivariate structural model with common trends, January 1998 to July 2011

(Index values)
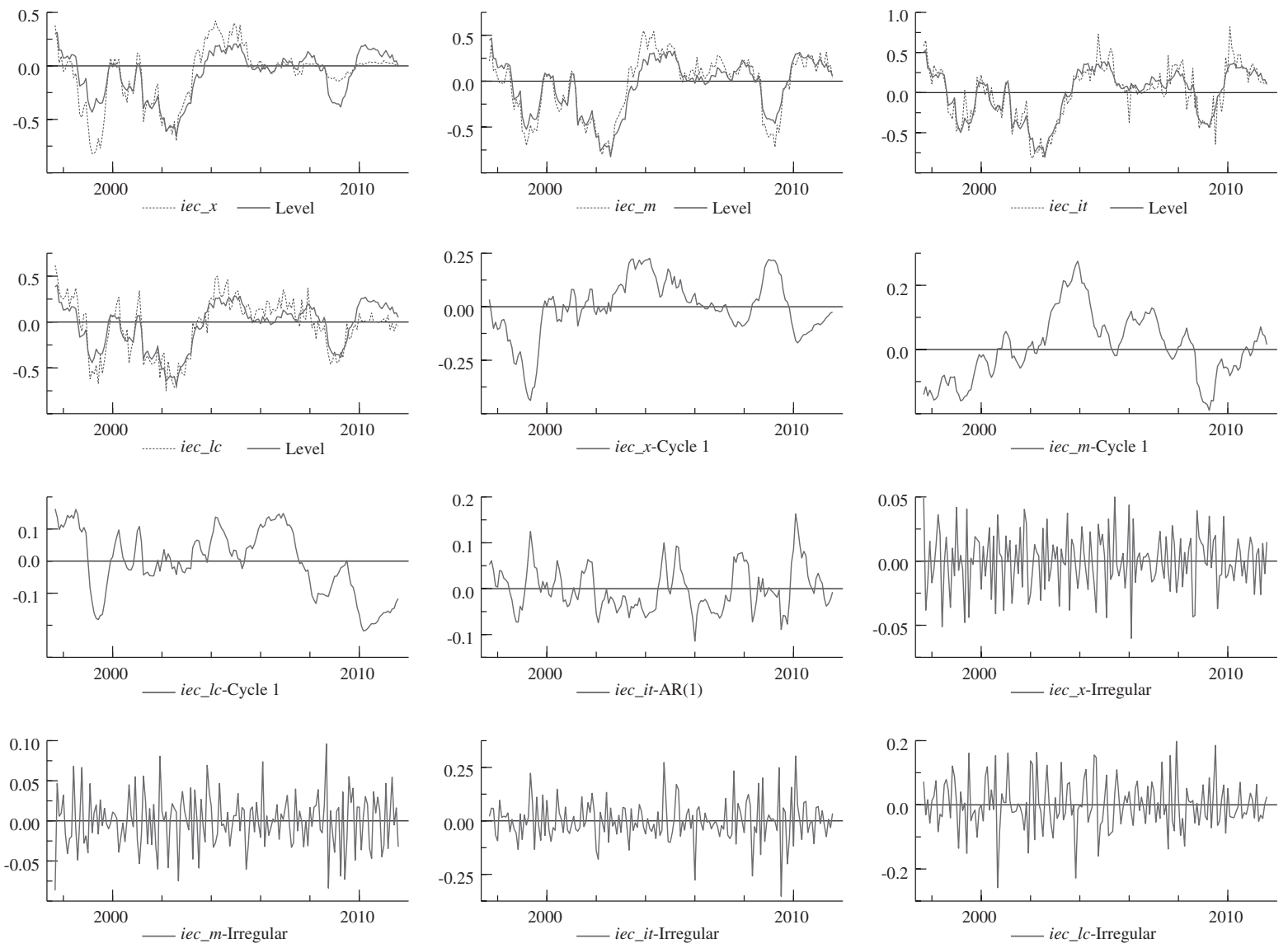

Source: prepared by the author. 
where $\mu_{t}^{*}$ is a univariate random walk. Therefore, the level components have the following relationship:

$$
\begin{aligned}
& \mu_{i e c \_m t}=1.334 \mu_{i e c \_x t}+0.05132, \\
& \mu_{i e c \_i t t}=1.374 \mu_{i e c \_x t}+0.09907, \\
& \mu_{i e c \_l c t}=1.135 \mu_{i e c \_x t}+0.04753,
\end{aligned}
$$

where the common trend is the one estimated for export industries: $\mu_{i e c \_x t}$.

\section{Expectations and industrial production in a multisectoral model}

On the basis of the findings for the above points, a multisectoral model incorporating the variables of expectations and sectoral industrial production was estimated and yielded the impulse-response simulations presented in figure 7 .

FIGURE 7

Impulse-response representations from the VAR model of expectations and sectoral industrial production

(Shock simulated: 1 standard deviation; 12 periods)
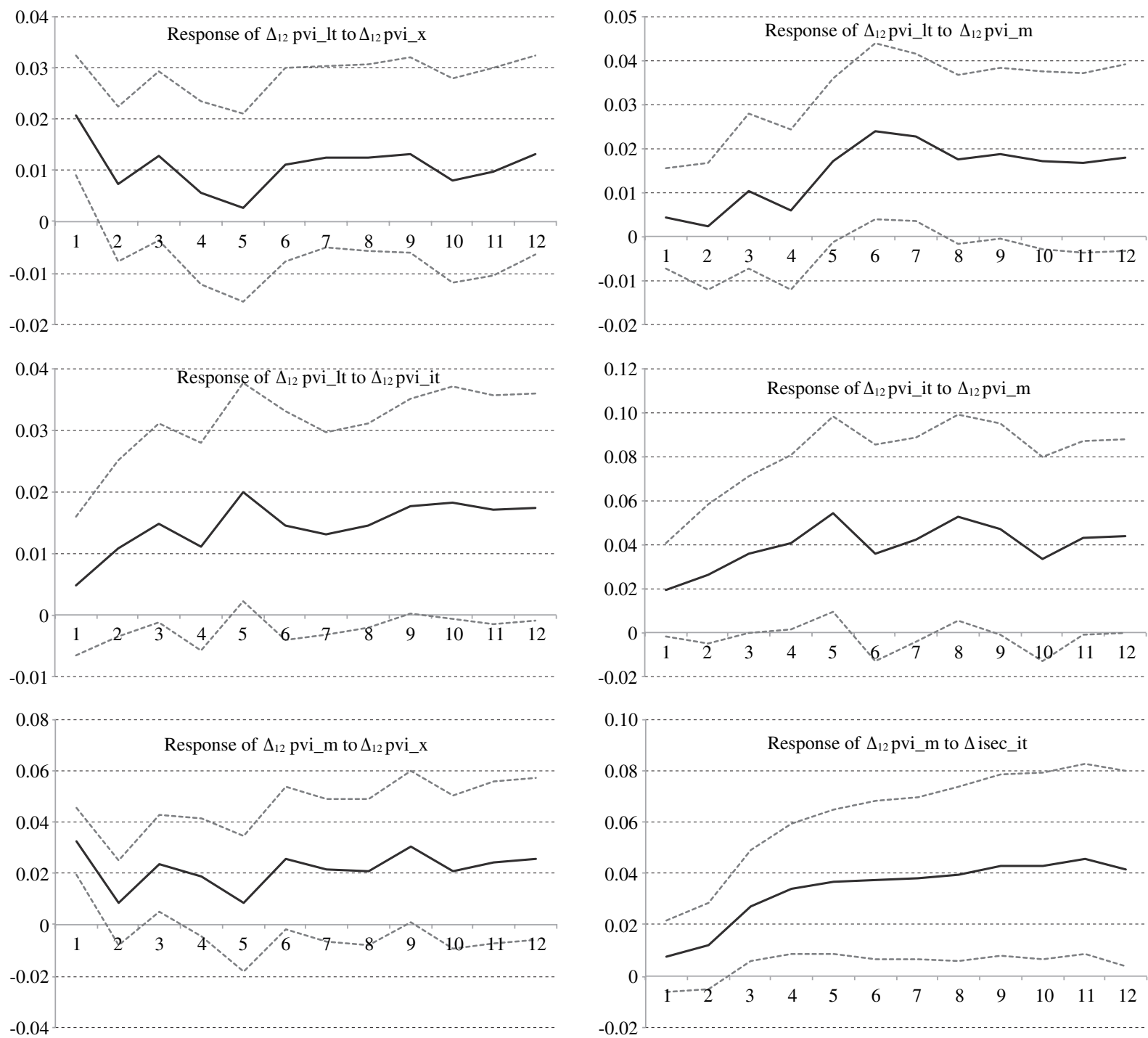

Source: prepared by the author.

Note: only significant responses are included. Impacts on the grouping itself are not included. Confidence intervals are standard errors calculated using Monte Carlo simulations (with 1,000 repetitions). Responses are cumulative.

$\Delta_{12}$. twelfth difference. VAR: multisectoral vector autoregression model. 
The VAR model and its simulations demonstrate once more that industries producing for the external market are net recipients of shocks that initially affect the other industries, with their greater trading profile and exposure to international competition. Intersectoral influences can also be observed between the importsubstitution and intra-branch trade groupings and from export industries to the former.

\section{VIII}

\section{Main conclusions}

This study, which is predominantly empirical and exploratory in nature, provides evidence on some aspects of the formation of industrialists' expectations and sheds light on how these ultimately affect levels of industrial production. The main results are summarized below.

The research confirms what a number of international studies have maintained, among the most recent being Kangasniemi, Kangassalo and Takala (2010) and Kangasniemi and Takala (2012): that business expectation variables provide information of value for anticipating and predicting the future course of production. This study on Uruguayan industry confirms that the perceptions industrialists form of future economic developments and their own industry sector are leading indicators of future sectoral performance in local manufacturing industry.

The results show that these forward-looking indicators follow the same long-term trajectory as industrial production in the sector to which they relate. Even in the two largest industry groupings, they precede developments in a strict sense (by at least six months). The survey ascertains expectations for the coming six months, which would suggest that industrialists make decisions fully in line with their stated expectations. The results match those reported in numerous international research projects and previous studies on Uruguay, which have highlighted the relevance of such indicators for predicting developments in overall economic activity. Indicators reflecting the opinion of economic agents are widely used around the world, especially in countries with well-developed statistical systems.

Analysis involving the breakdown of industry into groupings characterized by trade participation and productive specialization provides a way of considering how expectations are transmitted (or spread) among industrialists. Macroeconomic expectations in the four industry groupings are found to follow a single common trajectory that is ultimately determined by expectations in the export grouping. The same results emerge from cointegration analysis and estimation of the underlying common trend from multivariate structural models. The impulse-response simulations produced by the errorcorrection model estimated, which reveals the short-term dynamics of sectoral responses, reaffirm the importance of export industries in spreading macroeconomic expectation shocks.

No cointegrating relationships linking sectoral expectations in all four industry groupings were found, so the influences between sectors were studied using a multisectoral VAR model in first differences. The results again highlighted the significant role played by the most trade-oriented industries in spreading expectation shocks. The multisectoral VAR models of expectations and industrial production confirm that there is cross-sectoral influence both in expectations and in actual production, and corroborate previous findings as to which groupings are most influential.

The key role played by the most trade-oriented industries tallies with these groupings' large share of industrial production. Export industries account for over $50 \%$ of industrial GVP and nearly $40 \%$ of GVA (excluding the State oil refinery), while import-substitution industries account for more than $20 \%$ of the industry total on each measure. As the latter's production structure suggests, they have a backward spillover effect because of the enormous share of production expenditure represented by inputs, particularly those sourced domestically. These findings match those of Long and Plosser (1983), Gordon (1981) and Blanchard (1987).

Besides their representativeness in terms of industrial production, these industries' greater exposure to international trade makes them more competitive and provides them with access to extensive and complete information on the relevant macroeconomic and international context. Conversely, the intrabranch trade and low-trade sectors play less of a role in spreading expectations. In particular, industries producing for the domestic market seem more likely to be recipients than senders of expectation signals. 
The learning hypothesis of Eusepi and Preston (2008), which they make the basis for the transmission of expectations resulting in economic fluctuations, may also explain the findings of this research. This learning is held to take place among agents who do not receive information directly.

The identification of a common trend in industrialists' expectations about the future of the economy, guided by the expectations of the export grouping, reveals and reflects the production structure of what is clearly an open economy whose dynamics are highly dependent on the long-term performance of the external sector. Although this research is exploratory, its findings have potentially important implications for economic policy. The influence of the most trade-oriented industries on expectations and then on sectoral production is a pointer for policymakers seeking to mould expectations and create a climate of optimism during recessions so that their duration is lessened. The question of which factors ultimately determine expectations in these key sectors is certainly one of the issues raised by this study, and could be the subject of future research. 
ANNEX I

TABLE A.1

\section{Econometrics}

Unit root tests

(ADF and KPSS)

\begin{tabular}{|c|c|c|c|}
\hline \multirow{2}{*}{ Period: January 1998-July 2011} & \multicolumn{2}{|c|}{$\begin{array}{c}\text { Augmented Dickey-Fuller (ADF) test } \\
\mathrm{H}_{0}=\text { presence of unit root }\end{array}$} & \multirow{2}{*}{$\begin{array}{l}\text { Kwiatkowski, Phillips, Schmidt and } \\
\text { Shin (KPSS) test } \mathrm{H}_{0}=\text { stationarity } \\
\text { Value of the statistic in levels }\end{array}$} \\
\hline & $\begin{array}{l}\text { Value of the statistic } \\
\text { in levels }\end{array}$ & $\begin{array}{l}\text { Value of the statistic } \\
\text { in first difference }\end{array}$ & \\
\hline $\begin{array}{l}\text { Export industries' expectations } \\
\left(i e c \_x\right)\end{array}$ & $\begin{array}{c}-2.173^{*} \\
\text { (5 lags, without test) } \\
-2.243 \\
(0 \text { lags, with test })\end{array}$ & $\begin{array}{c}-5.194 \\
\text { (4 lags, without test) }\end{array}$ & $\begin{array}{c}0.492 * \\
\text { (Bandwidth: } 10, \text { test) }\end{array}$ \\
\hline $\begin{array}{l}\text { Low-trade industries' expectations } \\
\left(i e c \_l t\right)\end{array}$ & $\begin{array}{c}-2.541^{*} \\
\text { (4 lags, without test) } \\
-2.993 \\
\text { (1 lag, with test) }\end{array}$ & $\begin{array}{c}-11.335 \\
(1 \mathrm{lag}, \text { without test })\end{array}$ & $\begin{array}{c}0.546^{*} \\
\text { (Bandwidth: } 2, \text { test) }\end{array}$ \\
\hline $\begin{array}{l}\text { Import-substitution industries' expectations } \\
\left(i e c \_m\right)\end{array}$ & $\begin{array}{c}-2.199 * \\
(0 \text { lags, without test }) \\
-2.216 \\
(0 \text { lags, with test })\end{array}$ & $\begin{array}{c}-12.373 \\
(0 \text { lags, without test })\end{array}$ & $\begin{array}{c}0.523^{*} \\
\text { (Bandwidth: } 6 \text {, test) }\end{array}$ \\
\hline $\begin{array}{l}\text { Intra-branch trade industries' expectations } \\
\text { (iec_it) }\end{array}$ & $\begin{array}{c}-2.485^{*} \\
\text { (3 lags, without test) } \\
-2.737 \\
\text { (2 lags, with test) }\end{array}$ & $\begin{array}{c}-9.590^{*} \\
\text { (2 lags, without test) }\end{array}$ & $\begin{array}{c}0.518^{*} \\
\text { (Bandwidth: } 6 \text {, test) }\end{array}$ \\
\hline $\begin{array}{l}\text { Export industries' sectoral expectations } \\
(\text { isec_x })\end{array}$ & $\begin{array}{c}-2.173^{*} \\
\text { (5 lags, without test) } \\
-2.243 \\
\text { (5 lags, with test) }\end{array}$ & $\begin{array}{c}-5.194^{*} \\
\text { (4 lags, without test) }\end{array}$ & $\begin{array}{c}0.469 * \\
\text { (Bandwidth: } 10, \text { test) }\end{array}$ \\
\hline $\begin{array}{l}\text { Low-trade industries' sectoral expectations } \\
\text { (isec_lt) }\end{array}$ & $\begin{array}{c}-2.569^{*} \\
\text { (3 lags, without test) } \\
-2.787 \\
\text { (2 lags, with test) }\end{array}$ & $\begin{array}{c}-13.364^{*} \\
(1 \mathrm{lag}, \text { without test })\end{array}$ & $\begin{array}{c}0.479 * \\
\text { (Bandwidth: } 8, \text { test) }\end{array}$ \\
\hline $\begin{array}{l}\text { Import-substitution industries' } \\
\text { sectoral expectations } \\
\left(i s e c \_m\right)\end{array}$ & $\begin{array}{c}-2.236^{*} \\
(0 \text { lags, without test }) \\
-2.339 \\
(0 \text { lags, with test })\end{array}$ & $\begin{array}{c}-13.807^{*} \\
\text { (0 lags, without test) }\end{array}$ & $\begin{array}{c}0.506^{*} \\
\text { (Bandwidth: } 10, \text { test) }\end{array}$ \\
\hline $\begin{array}{l}\text { Intra-branch trade industries' } \\
\text { sectoral expectations } \\
(\text { isec_it) }\end{array}$ & $\begin{array}{c}-1.914 \\
(2 \text { lags, without test) } \\
-2.091 \\
\text { (2 lags, with test) }\end{array}$ & $\begin{array}{c}-12.298 * \\
(1 \text { lag, without test) }\end{array}$ & $\begin{array}{c}0.490 * \\
\text { (Bandwidth: } 102, \text { test) }\end{array}$ \\
\hline $\begin{array}{l}\left.\text { Exporters' PVI ( } p v i \_x\right) \\
\text { In lags, seasonally differentiated }\end{array}$ & $\begin{array}{c}-1.560 \\
(4 \text { lags, without test) } \\
-1.560 \\
\text { (4 lags, with test) }\end{array}$ & $\begin{array}{l}-5.141 * \\
(11 \text { lags, without test })\end{array}$ & $\begin{array}{c}0.532 * \\
\text { (Bandwidth: } 1 \text {, test) }\end{array}$ \\
\hline $\begin{array}{l}\text { Low-trade industry PVI }\left(p v i \_l t\right) \\
\text { In logs, seasonally differentiated }\end{array}$ & $\begin{array}{c}-1.790 \\
(13 \text { lags, without test }) \\
-1.829 \\
\text { (13 lags, with test) }\end{array}$ & $\begin{array}{l}-6.097 * \\
\text { (13 lags, without test) }\end{array}$ & $\begin{array}{c}0.537355^{*} \\
\text { (Bandwidth: } 9, \text { test) }\end{array}$ \\
\hline $\begin{array}{l}\left.\text { Import-substitution industry PVI ( } p v i \_m\right) \\
\text { In logs, seasonally differentiated }\end{array}$ & $\begin{array}{c}-2.558 \\
\text { (12 lags, without test) } \\
-2.567 \\
\text { (12 lags, with test) }\end{array}$ & $\begin{array}{l}-9.236^{*} \\
\text { (11 lags, without test) }\end{array}$ & $\begin{array}{c}0.559^{*} \\
\text { (Bandwidth: } 3 \text {, test) }\end{array}$ \\
\hline $\begin{array}{l}\left.\text { Intra-industry trade PVI ( } p v i \_i t\right) \\
\text { In logs, seasonally differentiated }\end{array}$ & $\begin{array}{c}-2.225^{*} \\
\text { (14 lags, without test) } \\
-2.861 \\
\text { (13 lags, with test) }\end{array}$ & $\begin{array}{l}-7.316^{*} \\
\text { (11 lags, without test) }\end{array}$ & $\begin{array}{c}0.545^{*} \\
\text { (Bandwidth: } 9 \text {, test) }\end{array}$ \\
\hline
\end{tabular}

Source: author's estimates.

Note: the test specification is given in parentheses. The number of lags was determined using the Akaike information criterion (AIC). The Newey-West procedure was used to select bandwidth. * Rejection of the null hypothesis at $95 \%$. 
TABLE A. 2

Cointegration tests ${ }^{a}$

Equation 1 [DLOG(pvi_x, 0.12), iec_x] - Adjusted sample: Oct 2000-Jul 2011, 130 observations

\begin{tabular}{lcccc}
\hline No. of cointegrating relationships & $\begin{array}{c}\text { Characteristic } \\
\text { value }\end{array}$ & Trace statistic & Probability & $\begin{array}{c}\text { Maximum } \\
\text { characteristic value }\end{array}$ \\
\hline None & 0.209096 & 36.20674 & $0.0002 * *$ & 30.49524 \\
At least 1 & 0.042983 & 5.711503 & 0.2142 & $0.0001 * *$ \\
\hline
\end{tabular}

Restricted constant, lags: 1, 4, 12

Exogenous: atypical. Date = Jan 2001 Date = Apr 2001 Date = Dec 2001 D(Date = Aug 2002) Date = Apr 2003 Date = Apr 2009; effect of special days: $\mathrm{D}(\mathrm{CARNI}) \mathrm{D}(\mathrm{EASTER})$

Equation 2 [DLOG(pvi_m, 0.12), iec_m] - Adjusted sample: Oct 2000-Jul 2011, 130 observations

\begin{tabular}{lcccc} 
No. of cointegrating relationships & $\begin{array}{c}\text { Characteristic } \\
\text { value }\end{array}$ & $\begin{array}{c}\text { Trace statistic } \\
\text { Probability }\end{array}$ & $\begin{array}{c}\text { Maximum } \\
\text { characteristic value }\end{array}$ & Probability \\
\hline None & 0.135876 & 25.26535 & $0.0094 * *$ & 15.8921 \\
At least 1 & 0.047161 & 6.280279 & 0.1702 & 9.164546 \\
\hline
\end{tabular}

Restricted constant, lags: 1, 6, 12

Exogenous: atypical. D(Date $\geq$ Apr 2001) D(Date $\geq$ Feb 2003) D(Date = Sep 2003) D(Date $\geq$ Mar 2004) D(Date $\geq$ Apr 2008) D(Date $\geq$ Oct 2008); effect of special days: D(EASTER)

Equation 3 [DLOG(pvi_it,12), iec_it] - Adjusted sample: Oct 2000-Jul 2011, 130 observations

\begin{tabular}{|c|c|c|c|c|c|}
\hline No. of cointegrating relationships & $\begin{array}{c}\text { Characteristic } \\
\text { value }\end{array}$ & Trace statistic & Probability & $\begin{array}{l}\text { Maximum } \\
\text { characteristic value }\end{array}$ & Probability \\
\hline None & 0.211948 & 35.97638 & $0.0002 * *$ & 30.96483 & $0.0001 * *$ \\
\hline
\end{tabular}

Restricted constant, lags: 1, 2, 12

Exogenous: atypical. Date = Apr 2001 Date = Dec 2001 Date = Oct 2004 Date = Jan 2006 D(Date = Aug 2007) Date = May 2008 D $($ Date $=$ Aug 2008) Date $=$ Nov 2008 D(Date $=$ Jun 2009) Date $=$ Aug 2009 Date $=$ Dec 2009

Equation 4 [DLOG(pvi_lt,12), iec_lt] - Adjusted sample: Oct 2000-Jul 2011, 130 observations

\begin{tabular}{lcccc}
\hline No. of cointegrating relationships & $\begin{array}{c}\text { Characteristic } \\
\text { value }\end{array}$ & Trace statistic & Probability & $\begin{array}{c}\text { Maximum } \\
\text { characteristic value }\end{array}$ \\
\hline None & 0.162296 & 29.28397 & $0.0022 * *$ & 23.02179 \\
At least 1 & 0.047029 & 6.262182 & 0.1714 & $0.0032 * *$ \\
\hline
\end{tabular}

Restricted constant, lags: 1,12

Exogenous: atypical. Date = Apr 2001 D(Date = Mar 2002) Date = Feb 2003; effect of special days: D(EASTER) D(CARNI)

Equation 5 [DLOG(pvi_x, 0,12), isec_x] - Adjusted sample: Oct 2000-Jul 2011, 130 observations

\begin{tabular}{|c|c|c|c|c|c|}
\hline No. of cointegrating relationships & $\begin{array}{c}\text { Characteristic } \\
\text { value }\end{array}$ & Trace statistic & Probability & $\begin{array}{c}\text { Maximum } \\
\text { characteristic value }\end{array}$ & Probability \\
\hline None & 0.203634 & 32.59118 & $0.0006^{* *}$ & 29.60053 & $0.0002 * *$ \\
\hline At least 1 & 0.022742 & 2.990645 & 0.5824 & 2.990645 & 0.5824 \\
\hline
\end{tabular}

Restricted constant, lags: $1,5,12$

Exogenous: atypical. Date = Dec 2000 Date = Apr 2001 D(Date = Oct 2001) Date = Sep 2002; effect of special days: D(EASTER)

$\mathrm{D}(\mathrm{CARNI})$

Equation 6 [DLOG(pvi_m, 0,12), isec_m] - Adjusted sample: Oct 2000-Jul 2011, 139 observations

\begin{tabular}{|c|c|c|c|c|c|}
\hline No. of cointegrating relationships & $\begin{array}{c}\text { Characteristic } \\
\text { value }\end{array}$ & Trace statistic & Probability & $\begin{array}{l}\text { Maximum } \\
\text { characteristic value }\end{array}$ & Probability \\
\hline None & 0.177562 & 34.17117 & $0.0003 * *$ & 25.41263 & $0.0012 * *$ \\
\hline At least 1 & 0.065154 & 8.758538 & 0.0597 & 8.758538 & 0.0597 \\
\hline
\end{tabular}

Restricted constant, lags: 1, 3, 12

Exogenous: atypical. D(Date $\geq$ Apr 2001) D(Date $\geq$ Aug 2002) D(Date $\geq$ Mar 2004) D(Date $\geq$ Oct 2008); effect of special days: D(EASTER) 
Table A.2 (concluded)

Equation 7 [DLOG(pvi_it,12), isec_it] - Adjusted sample: Oct 2000-Jul 2011, 138 observations

\begin{tabular}{lcccc}
\hline No. of cointegrating relationships & $\begin{array}{c}\text { Characteristic } \\
\text { value }\end{array}$ & Trace statistic & Probability & $\begin{array}{c}\text { Maximum } \\
\text { characteristic value }\end{array}$ \\
\hline None & 0.103872 & 21.52488 & $0.0333^{*}$ & 15.13478 \\
At least 1 & 0.045249 & 6.390104 & 0.1627 & 0.0654 \\
\hline
\end{tabular}

Restricted constant, lags: 1,4

Exogenous: atypical. D(Date $=$ Dec 2001) D(Date $\geq$ Sep 2004) D(Date $=$ Jul 2007)

Equation 8 [DLOG(pvi_lt,12), isec_lt] - Adjusted sample: Oct 2000-Jul 2011, 130 observations

\begin{tabular}{|c|c|c|c|c|c|}
\hline No. of cointegrating relationships & $\begin{array}{c}\text { Characteristic } \\
\text { value }\end{array}$ & Trace statistic & Probability & $\begin{array}{c}\text { Maximum } \\
\text { characteristic value }\end{array}$ & Probability \\
\hline None & 0.323584 & 56.92973 & $0.0000^{* *}$ & 50.82308 & $0.0000 * *$ \\
\hline At least 1 & 0.045888 & 6.106644 & 0.1827 & 6.106644 & 0.1827 \\
\hline
\end{tabular}

Restricted constant, lags: 1, 5, 12

Exogenous: atypical. D(Date $\geq$ Feb 2003) D(Date $\geq$ Feb 2008) D(Date $\geq$ Dec 2008); effect of special days: D(EASTER) D(CARNI)

Equations 9-11 [iec_lt, iec_x, iec_it, iec_m ] - Adjusted sample: Nov 1997-Jul 2011, 165 observations

\begin{tabular}{|c|c|c|c|c|c|}
\hline No. of cointegrating relationships & $\begin{array}{c}\text { Characteristic } \\
\text { value }\end{array}$ & Trace statistic & Probability & $\begin{array}{c}\text { Maximum } \\
\text { characteristic value }\end{array}$ & Probability \\
\hline None & 0.268718 & 107.9238 & $0.0000 * *$ & 51.63786 & $0.0000 * *$ \\
\hline At least 1 & 0.194458 & 56.28598 & $0.0001 * *$ & 35.67963 & $0.0004 * *$ \\
\hline At least 2 & 0.081527 & 20.60635 & $0.0448^{*}$ & 14.03212 & 0.0958 \\
\hline At least 3 & 0.039061 & 6.574237 & 0.1508 & 6.574237 & 0.1508 \\
\hline
\end{tabular}

Restricted constant, lags: 1
Exogenous: atypical. D(Date $\geq$ May 1999) D(Date $\geq$ Apr 2001) D(Date $\geq$ Dec 2001) D(Date = Mar 2002) D(Date $\geq$ Jan 2006) D(Date $\geq$ Aug 2007) D(Date = Oct 2008) D(Date $\geq$ Dec 2009) D(Date $\geq$ Feb 2010)

Source: prepared by the author.

a See Section VII, points 1 and 2 .

Note: $* *$ Significant at $1 \%$; $*$ significant at $5 \%$.

TABLE A.3

Normality tests: equations 1 to 11

(Residual normality test)

\begin{tabular}{lcccc}
\hline & $\begin{array}{c}\text { Asymmetry } \\
\text { (probability) }\end{array}$ & $\begin{array}{c}\text { Kurtosis } \\
\text { (probability) }\end{array}$ & Jarque-Bera & Probability (J-B) \\
\hline Equation 1 & 0.9187 & 0.1246 & 4.335119 & 0.3625 \\
Equation 2 & 0.1724 & 0.4442 & 5.138588 & 0.2734 \\
Equation 3 & 0.4717 & 0.7125 & 2.180904 & 0.7025 \\
Equation 4 & 0.7961 & 0.3879 & 2.349808 & 0.6717 \\
Equation 5 & 0.9526 & 0.1809 & 3.516415 & 0.4754 \\
Equation 6 & 0.3138 & 0.4853 & 3.763709 & 0.4389 \\
Equation 7 & 0.0662 & 0.7151 & 6.101225 & 0.1917 \\
Equation 8 & 0.209 & 0.8225 & 3.521203 & 0.4747 \\
Equation 9 & 0.6125 & 0.2853 & 7.701276 & 0.4632 \\
Equation 10 & & & & \\
Equation 11 & & & & \\
\hline
\end{tabular}

Source: prepared by the author.

a On the three-equation system.

Note: orthogonalization: Cholesky (Lutkepohl). $\mathrm{H}_{0}$ : multivariate normal residuals. 
Exclusion tests: equations 1 to 11

\begin{tabular}{|c|c|c|c|c|c|c|c|c|}
\hline & \multicolumn{2}{|c|}{$\beta_{1}=0$} & \multicolumn{2}{|c|}{$\beta_{2}=0$} & \multicolumn{2}{|c|}{$\beta_{3}=0$} & \multicolumn{2}{|c|}{$\beta_{4}=0$} \\
\hline & $\begin{array}{c}\text { Chi } \\
\text { squared }\end{array}$ & Probability & $\begin{array}{c}\text { Chi } \\
\text { squared }\end{array}$ & Probability & $\begin{array}{c}\text { Chi } \\
\text { squared }\end{array}$ & Probability & $\begin{array}{c}\text { Chi } \\
\text { squared }\end{array}$ & Probability \\
\hline $\begin{array}{l}\text { Equation } 1 \\
\left(\operatorname{ECM}\left[\Delta 12 p v i \_x, i e c \_x\right]\right)\end{array}$ & 24.112 & 0.000 & 11.708 & 0.001 & - & - & - & - \\
\hline $\begin{array}{l}\text { Equation } 2 \\
\left(\mathrm{ECM}\left[\Delta 12 p v i \_m, i e c \_m\right]\right) \\
\text { Equation } 3\end{array}$ & 11.530 & 0.001 & 10.830 & 0.001 & - & - & - & - \\
\hline $\begin{array}{l}(\mathrm{ECM}[\Delta 12 p v i \text { it, iec_it }]) \\
\text { Equation } 4\end{array}$ & 29.173 & 0.000 & 23.048 & 0.000 & - & - & - & - \\
\hline $\begin{array}{l}\left(\mathrm{ECM}\left[\Delta 12 p v i \_l t, i e c \_l t\right]\right) \\
\text { Equation } 5\end{array}$ & 18.048 & 0.000 & 13.915 & 0.000 & - & - & - & - \\
\hline $\begin{array}{l}\left(\operatorname{ECM}\left[\Delta 12 p v i \_x, i s e c \_x\right]\right) \\
\text { Equation } 6\end{array}$ & 26.453 & 0.000 & 12.060 & 0.001 & - & - & - & - \\
\hline $\begin{array}{l}\left(\mathrm{ECM}\left[\Delta 12 p v i \_m, \text { isec_m }\right]\right) \\
\text { Equation } 7\end{array}$ & 16.376 & 0.000 & 9.367 & 0.002 & - & - & - & - \\
\hline $\begin{array}{l}\left(\mathrm{ECM}\left[\Delta 12 p v i \_i t, i s e c \_i t\right]\right) \\
\text { Equation } 8\end{array}$ & 7.898 & 0.005 & 6.031 & 0.014 & - & - & - & - \\
\hline $\begin{array}{l}\left(\mathrm{ECM}\left[\Delta 12 p v i \_l t, i e c \_l t\right]\right) \\
\text { Equation } 9\end{array}$ & 38.182 & 0.000 & 40.487 & 0.000 & - & - & - & - \\
\hline $\begin{array}{l}{\left[i e c \_x \text {, iec_m, iec_it, iec_lt] }\right.} \\
\text { Equation } 10\end{array}$ & 26.723 & 0.008 & 30.282 & 0.003 & - & - & - & - \\
\hline $\begin{array}{l}{\left[i e c \_x \text {, iec_m, iec_it, iec_lt] }\right.} \\
\text { Equation } 11\end{array}$ & - & - & 36.835 & 0.000 & 43.906 & 0.000 & & - \\
\hline$\left[i e c \_x, i e c \_m\right.$, iec_it, iec_lt] & 34.166 & 0.001 & - & - & - & - & 31.658 & 0.002 \\
\hline
\end{tabular}

Source: prepared by the author.

Note: in equations 9, 10 and 11, the tests were performed on the restricted system so that all vectors were identified. ECM: error-correction mechanism coefficient.

TABLE A.5

\section{Causality tests}

\begin{tabular}{|c|c|c|}
\hline Null hypothesis: & F-statistic & Probability \\
\hline $\operatorname{DLOG}\left(p v i \_x, 0.12\right)$ does not Granger-cause $i e c \_x$ & 1.2826 & 0.2378 \\
\hline$i e c \_x$ does not Granger-cause DLOG $\left(p v i \_x, 0.12\right)$ & 1.7887 & 0.0576 \\
\hline DLOG(pvi_m, 0.12) does not Granger-cause $i e c \_m$ & 0.7361 & 0.7137 \\
\hline$i e c \_m$ does not Granger-cause DLOG(pvi_m, $\left.0 . \overline{12}\right)$ & 2.5935 & 0.0043 \\
\hline $\operatorname{DLOG}\left(p v i \_l t, 0.12\right)$ does not Granger-cause $i e c \_l t$ & 0.6698 & 0.7773 \\
\hline$i e c \_l t$ does not Granger-cause DLOG(pvi_lt, $\left.0 . \overline{12}\right)$ & 1.6562 & 0.0855 \\
\hline $\operatorname{DLOG}\left(p v i \_x, 0.12\right)$ does not Granger-cause $i s e c \_x$ & 0.9598 & 0.4910 \\
\hline$i s e c \_x$ does not Granger-cause DLOG $\left(p v i \_x, 0.12\right)$ & 2.2826 & 0.0120 \\
\hline DLŌG(pvi_m, 0.12) does not Granger-cause $i s e c \_m$ & 1.0471 & 0.4113 \\
\hline$i s e c \_m$ does not Granger-cause DLOG $\left(p v i \_m, 0.12\right)$ & 2.4495 & 0.0069 \\
\hline
\end{tabular}

Source: prepared by the author. 
ANNEX II

\section{Cointegration and common trends}

The existence of cointegration between two integrated time series implies a trend common to both. The basis for identifying common trends between time series is the application of multivariate structural models. The methodological framework for thus identifying common trends and common factors more generally was developed by Engle and Kozicki (1993) and Vahid and Engle (1993) and applied in a number of studies, such as Carvalho and Harvey (2005) and Carvalho, Harvey and Trimbur (2007).

To that end, take the multivariate local oscillation model relative to the variable of the level component (the development is based on Koopman and others, 2009):

$$
\begin{array}{ll}
y_{t}=\mu_{t}+\varepsilon_{t}, & \varepsilon_{t} \sim \operatorname{NID}\left(0, \Sigma_{\varepsilon}\right) \\
\mu_{t}=\mu_{t-1}+\eta_{t}, & \eta_{t} \sim \operatorname{NID}\left(0, \sum_{\eta}\right)
\end{array}
$$

where $\sum_{\varepsilon}$ and $\sum_{\eta}$ are variance-covariance matrices and $\eta_{t}$ and $\varepsilon_{t}$ are normal disturbances uncorrelated with each other in all periods. Now suppose that the range of $\sum_{\eta}$ is $K<N$. In this case, the model contains $K$ levels or common trends, and can be written as:

$$
\begin{array}{ll}
y_{t}=\Theta \mu_{t}^{*}+\varepsilon_{t}, & \varepsilon_{t} \sim \operatorname{NID}\left(0, \sum_{\varepsilon}\right) \\
\mu_{t}^{*}=\mu_{t-1}^{*}+\eta_{t}^{*}, & \eta_{t}^{*} \sim \operatorname{NID}\left(0, D_{\eta}\right)
\end{array}
$$

where $\eta_{t}^{*}$ is a $K \times 1$ vector, $\Theta$ is an $N$ x $K$ standardized factor loading matrix, $D_{\eta}$ is a diagonal matrix and $\mu$ is an $N$ x 1 constant vector, in which the first $N$ - $K$ elements are null and the remaining $K$ elements are contained within a $\bar{\mu}$. vector. The $\Theta$ matrix consists of $K$ rows and has ones in the diagonal, so that $\theta_{i i}=1, i=1, \ldots \ldots . ., K$, while $\theta_{i j}=0$ whenever $j>i$.

To estimate both levels and common slopes, take a general multivariate local linear trend model in which the level variance matrix is of rank $K_{\eta}$ and the slope variance matrix is of rank $K_{\beta}$ :

$$
\begin{array}{ll}
y_{t}=\mu_{t}+\varepsilon_{t}, & \varepsilon_{t} \sim \operatorname{NID}\left(0, \sum_{\varepsilon}\right), \\
\mu_{t}=\mu_{t-1}+\Theta_{\beta} \beta_{t-1}^{*}+\beta_{\theta}+\eta_{t}, & \eta_{t} \sim \operatorname{NID}\left(0, \sum_{\eta}\right), \\
\beta_{t}^{*}=\beta_{t-1}^{*}+\zeta_{t}^{*}, & \zeta_{t}^{*} \sim \operatorname{NID}\left(0, D_{\zeta}\right)
\end{array}
$$

where the $N$ x $K_{\beta}$ matrix $\Theta_{\beta}$ is such that e $\sum_{\zeta} \Theta_{\beta} D_{\zeta} \Theta_{\beta}^{\prime}$, $\beta_{\theta}=\left(0^{\prime}, \overline{\beta^{\prime}}\right)^{\prime}$ with $\bar{\beta}$ a vector of length $\left(\mathrm{N}-K_{\beta}\right)$. If $K_{\beta}=1$ ( $\Theta_{\beta}$ is a vector of ones), letting $\bar{\beta}=0$, the inference is that all the series have the same underlying growth rate (when modelling in logarithms). This is possible even where there are no common levels. The implication is that the trends in the prediction function remain parallel, in other words the long-run growth paths are the same. However, unless there are similar restrictions on the levels, the growth paths within the sample will not necessarily stay together.

In a common trend model such as the one given in equation A.2, a cointegrated system is expressly established, given the restrictions on the number of unobservable components that it entails (Harvey, 1989). If the $y_{t}$ elements are integrated of order 1 (I(1)), there will be $N-K$ linear combinations of $y_{t}$ that are stationary. This means that there is a matrix of order $(N-K) \times N$ of cointegration vectors $A$, so that $A y_{t}$ is a stationary process $(N-K) \times 1$. It therefore follows that $\mathrm{A}^{\prime} \Theta=0$, and consequently:

$$
A y_{t}=A \mu+A \varepsilon_{t}
$$

The tests for identifying common trends in a multivariate structural model were developed by Nyblom and Harvey (2001). 


\section{Bibliography}

Alfarano, S. and M. Milakovic (2010), "Identification of interaction effects in survey expectations: a cautionary note", $B E R G$ Working Paper Series, No. 75, Bamberg, Bamberg Economic Research Group.

Batchelor, R.A. (1982), "Expectations, output and inflation: the European experience", European Economic Review, vol. 17, No. 1, Amsterdam, Elsevier.

Beaudry, P. and F. Portier (2007), "When can changes in expectations cause business cycle fluctuations in neo-classical settings?", Journal of Economic Theory, vol. 135, No. 1, Amsterdam, Elsevier.

(2006), "Stock prices, news, and economic fluctuations", American Economic Review, vol. 96, No. 4, Nashville, Tennessee, American Economic Association.

Berk, J.M. (1999), "Measuring inflation expectations: a survey data approach", Applied Economics, vol. 31, No. 11, Taylor \& Francis.

Blanchard, O.J. (1987), "Aggregate and individual price adjustments", Brookings Papers on Economic Activity, No. 1, Washington, D.C., The Brookings Institution.

Caballero, R.J. and R.K. Lyons (1990), "Internal versus external economies in the European industry", European Economic Review, vol. 34, No. 4, Amsterdam, Elsevier.

Carvalho, V. and A. Harvey (2005), "Growth, cycles and convergence in US regional time series", International Journal of Forecasting, vol. 21, No. 4, Amsterdam, Elsevier.

Carvalho, V., A. Harvey and T. Trimbur (2007), "A note on common cycles, common trends and convergence", Journal of Business \& Economic Statistics, vol. 25, Taylor \& Francis.

Chan-Lee, J. (1980), "A review of recent work in the area of inflationary expectations", Review of World Economics, vol. 116, No. 1, Springer.

Common, M. (1985), "Testing for rational expectations with qualitative survey data", The Manchester School, vol. 53, No. 2, Wiley.

Conrad, Ch. and K. Loch (2011), “Anticipating long-run stock market volatility", Heidelberg, Heidelberg University.

Durlauf, S. (1991), "Path dependence in aggregate output", NBER Working Paper, No. 3718, Cambridge, Massachusetts, National Bureau of Economic Research.

Engle, R. and Sh. Kozicki (1993), "Testing for common features", Journal of Business \& Economic Statistics, vol. 11, No. 4, Alexandria, American Statistical Association.

Eusepi, S. and B. Preston (2008), "Expectations, learning and business cycle fluctuations", NBER Working Paper, No. 14181, Cambridge, Massachusetts, National Bureau of Economic Research.

Floden, M. (2007), "Vintage capital and expectations driven business cycles", CEPR Discussion Paper, No. 6113, London, Centre for Economic Policy Research.

Gordon, R. (1981), "Output fluctuations and gradual price adjustments", Journal of Economic Literature, vol. 19, No. 2, Pittsburgh, American Economic Association.

Hanssens, D.M. and P.M. Vanden Abeele (1987), "A time-series study of the formation and predictive performance of EEC production survey expectations", Journal of Business and Economic Statistics, vol. 5, No. 4, Taylor \& Francis.

Harvey, A.C. (1989), Forecasting, Structural Time Series Models and the Kalman Filter, Cambridge, Massachusetts, Cambridge University Press.

Johansen, S. (1995), Likelihood-Based Inference in Cointegrated Vector Autoregressive Models, Oxford, Oxford University Press.

Johansen, S. and K. Juselius (1989), "Maximum likelihood estimation and inference on cointegration, with applications to the demand for money", Oxford Bulletin of Economics and Statistics, vol. 52, No. 2, Oxford, University of Oxford.
Kangasniemi, J., P. Kangassalo and K. Takala (2010), "What affects the views about the economic sentiment? Evidence from the consumer and manufacturing surveys in Finland", paper presented at the $30^{\text {th }}$ CIRET Conference, New York.

Kangasniemi, J. and K. Takala (2012), "The role of expectation surprises in production decisions evidence from the Finnish manufacturing survey", paper presented at the $31^{\text {st }}$ CIRET Conference, Vienna.

Karnizova, L. (2010), "The spirit of capitalism and expectation-driven business cycles", Journal of Monetary Economics, vol. 57, No. 6, Amsterdam, Elsevier.

Kauppi, E., J. Lassila and T. Teräsvirta (1996), "Short-term forecasting of industrial production with business survey data: experience from Finland's great depression 1990-1993", International Journal of Forecasting, vol. 12, No. 3, Amsterdam, Elsevier.

Koopman, S.J. and others (2009), Structural Time Series Analyser, Modeller and Predictor: Stamp 8.2, London, Timberlake Consultants Ltd.

Laens, S. and R. Osimani (2000), "Patrones de comercio y desempeño exportador, el caso de Uruguay en los noventa", Montevideo, Centre for Economic Research.

Lanzilotta, B. (2006), "Aporte de los índices líderes de actividad económica al análisis de la coyuntura y la predicción macroeconómica en Uruguay", thesis, Montevideo, University of the Republic.

Leduc, S. and K. Sill (2010), "Expectations and economic fluctuations: an analysis using survey data", Working Paper Series, No. 2010-09, San Francisco, Federal Reserve Bank of San Francisco.

Lee, K. (1994), "Formation of price and cost inflation expectations in British manufacturing industries: a multi-sectoral analysis", The Economic Journal, vol. 104, No. 423, Wiley.

Lee, K. and M. Pesaran (1994), "An empirical analysis of business cycle fluctuations in the context of a multisectoral model-Full Report", University of Leicester/University of Cambridge.

Lee, K., M. Pesaran and R. Pierse (1992), "Persistence of shocks and their sources in a multisectoral model of UK output growth", Economic Journal, vol. 102, No. 411, Wiley.

Lee, K. and K. Shields (2000), "Expectations formation and business cycle fluctuations: an empirical analysis of actual and expected output in UK manufacturing, 1975-1996", Oxford Bulletin of Economics and Statistics, vol. 62, No. 4, Wiley.

Li, N. and M. Mehkari (2009), "Expectation Driven Firm Dynamics and Business Cycles", Columbus, Ohio, Ohio State University.

Litterman, H.S. (1980), "Techniques for Forecasting with Vector Autorregression", thesis, University of Minnesota

Long, J. and Ch. Plosser (1983), "Real business cycles", Journal of Political Economy, vol. 91, No. 1, Chicago, University of Chicago Press.

Lorenzo, F., B. Lanzilotta and I. Sueiro (2003), "Métodos cuantitativos para el análisis y predicción de la actividad industrial uruguaya", Documentos de trabajo, Montevideo, Centre for Economic Research.

Nardo, M. (2003), "The quantification of qualitative survey data: a critical assessment", Journal of Economic Surveys, vol. 17, No. 5, Wiley Blackwell.

Nardo, M. and M. Cabeza-Gutés (1999), “The role of measurement error in rational expectation testing", Working Paper, No. 451, Barcelona, Autonomous University of Barcelona.

Nyblom, J. and A. Harvey (2001), "Testing against smooth stochastic trends", Journal of Applied Econometrics, vol. 16, No. 3, Wiley.

Öller, L. (1990), "Forecasting the business cycle using survey data", International Journal of Forecasting, vol. 6, No. 4, Amsterdam, Elsevier, December.

Patel, S. (2011), "Economic Optimism, Information Uncertainty and Future Investment Decisions: Evidence from the Mutual Fund Industry", McGill University. 
Pesaran, M., R. Pierse and K. Lee (1993), "Persistence, cointegration and aggregation. A disaggregated analysis of output fluctuations in the U.S. economy", Journal of Econometrics, vol. 56, No. 1-2, Amsterdam, Elsevier.

Pesaran, M.H. and M. Weale (2006), "Survey expectations", Handbook of Economic Forecasting, vol. 1, G. Elliot, C. Granger and A. Timmermann (eds.), Amsterdam, North Holland.

Rahiala, M. and T. Teräsvirta (1993), "Business survey data in forecasting the output of Swedish and Finnish metal and engineering industries: a Kalman Filter approach", Journal of Forecasting, vol. 12, No. 3-4, Wiley.

Remond-Tiedrez, I. (2005), "From opinions to facts: links between short-term business statistics and business and consumer opinion surveys", Statistics in Focus. Industry, Trade and Services, No. 15/2005, Eurostat.

Smith, J. and M. McAleer (1995), "Alternative procedures for converting qualitative response data to quantitative expectations: an application to Australian manufacturing", Journal of Applied Econometrics, vol. 10, No. 2, Wiley.

Stock, J. and M. Watson (2001), "Vector autoregressions", Journal of Economic Perspectives, vol. 15, No. 4, Nashville, Tennessee, American Economic Association.

Svensson, L. (1997), "Inflation forecast targeting: implementing and monitoring inflation targets", European Economic Review, vol. 41, No. 6, Amsterdam, Elsevier.

Vahid, F. and R. Engle (1993), "Common trends and common cycles", Journal of Applied Econometrics, vol. 8, No. 4, Wiley. 